\title{
Suspension-Firing of Biomass
}

\section{Part 2, Boiler Measurements of Ash Deposit Shedding}

Shafique Bashir, Muhammad; Jensen, Peter Arendt; Frandsen, Flemming; Wedel, Stig; Dam-Johansen, Kim; Wadenback, Johan

\section{Published in:}

Energy \& Fuels

Link to article, DOI:

10.1021/ef300611v

Publication date:

2012

Document Version

Publisher's PDF, also known as Version of record

Link back to DTU Orbit

Citation (APA):

Shafique Bashir, M., Jensen, P. A., Frandsen, F., Wedel, S., Dam-Johansen, K., \& Wadenback, J. (2012). Suspension-Firing of Biomass: Part 2, Boiler Measurements of Ash Deposit Shedding. Energy \& Fuels, 26 , 5241-5255. https://doi.org/10.1021/ef300611v

\section{General rights}

Copyright and moral rights for the publications made accessible in the public portal are retained by the authors and/or other copyright owners and it is a condition of accessing publications that users recognise and abide by the legal requirements associated with these rights.

- Users may download and print one copy of any publication from the public portal for the purpose of private study or research.

- You may not further distribute the material or use it for any profit-making activity or commercial gain

- You may freely distribute the URL identifying the publication in the public portal 


\title{
Suspension-Firing of Biomass. Part 2: Boiler Measurements of Ash Deposit Shedding
}

\author{
Muhammad Shafique Bashir, ${ }^{\dagger}$ Peter Arendt Jensen, ${ }^{*}{ }^{\dagger}$ Flemming Frandsen, $^{\dagger}$ Stig Wedel, ${ }^{\dagger}$ \\ Kim Dam-Johansen, ${ }^{\dagger}$ and Johan Wadenbäck ${ }^{\ddagger}$ \\ ${ }^{\dagger}$ DTU Chemical and Biochemical Engineering, Building 229, Technical University of Denmark, DK-2800 Lyngby, Denmark \\ ${ }^{\ddagger}$ Vattenfall A/S, Amager Power Plant, Kraftværksvej 37, DK-2300 Copenhagen S, Denmark
}

\begin{abstract}
This paper is the second of two papers, describing probe measurements of deposit buildup and removal (shedding), conducted in a $350 \mathrm{MW}_{\text {th }}$ suspension-fired boiler, firing straw and wood. Investigations of deposit buildup and shedding have been made by use of an advanced online deposit probe and a sootblowing probe. The influences of feedstock (i.e., straw share in wood), flue gas temperature $\left(600-1050{ }^{\circ} \mathrm{C}\right)$, probe surface temperature $\left(500\right.$ and $\left.600{ }^{\circ} \mathrm{C}\right)$, and probe exposure time on deposit shedding have been quantified. Quantification of naturally occurring deposit shedding and deposit shedding during plant sootblowing was made via deposit mass uptake signals obtained from the deposit probe. The deposit shedding process was characterized by calculation of the amount of deposit removed at a shedding event $\left(\mathrm{g} / \mathrm{m}^{2}\right)$ and the frequency of the shedding events $\left(\mathrm{h}^{-1}\right)$. The results showed that the shedding process is stochastic and that the amount of deposit shed varies even at constant local conditions. However, the deposit shedding rates showed an increasing trend with increase in flue gas temperatures and probe deposit mass loads. The deposit shedding rate was in most cases higher at a probe temperature of 500 ${ }^{\circ} \mathrm{C}$ than at a probe temperature of $600{ }^{\circ} \mathrm{C}$. A possible reason for this is partial melting and/or sintering of the innermost deposit layer (rich in $\mathrm{K}, \mathrm{Cl}$, and $\mathrm{S}$ ) at higher probe surface temperature. This could cause the adhesion strength of the deposit to the probe to increase at the higher probe temperature. Quantification of the necessary peak impact pressure (PIP) needed to remove the deposit was also made by use of a sootblowing probe in conjunction with the deposit probe. Results of deposit removal by artificial sootblowing showed that the deposits formed on a $500{ }^{\circ} \mathrm{C}$ probe temperature and at exposure times of $<91 \mathrm{~h}$ can be removed with a PIP of $<55 \mathrm{kPa}$. However, increase in probe exposure time and/or probe surface temperature (600 ${ }^{\circ} \mathrm{C}$ ) significantly increases the PIP needed to remove the deposits.
\end{abstract}

\section{INTRODUCTION}

The focus on substituting fossil resources by biomass has significantly increased the interest in efficient use of biomass for electricity production, and this includes the use of wood or straw in large suspension-fired boilers. However, especially straw constitutes a serious technical challenge with respect to deposit formation and corrosion, due to the large content of $\mathrm{K}$ and $\mathrm{Cl}$ in straw. ${ }^{1-9}$ Deposit formation and corrosion problems limit the maximum applicable superheater temperature and, thereby, limit the electrical efficiency. In the case of severe ash deposition, boiler shutdown and expensive manual cleaning of the heat transfer surfaces may be needed. To minimize deposition problems, different strategies can be employed, for example, the use of additives that can convert gaseous inorganic species to less harmful forms, pretreatment of fuels by leaching out alkali, cofiring with coal, and the use of effective depositshedding techniques. ${ }^{10-16}$ Use of additives and pretreatment of fuels by leaching are less cost-effective compared to the use of effective deposit shedding techniques. $7,10-14$

Ash deposit buildup during biomass combustion is a dynamic process consisting of both deposit formation ${ }^{14,15}$ and shedding. ${ }^{12,14,16}$ The most common industrial methods used to shed deposits from superheater tubes include sootblowing, mechanical vibrations, detonation wave techniques, shotcleaning methods, thermal tensions, and rapping gear systems. Shedding may be initiated at the surface of the deposit, along the deposit tube interface, or inside the deposit depending on the local boiler conditions and the deposit properties. Important mechanisms of ash deposit shedding are ${ }^{14,16}$ (1) erosion, when nonsticky, relatively large, and sharp-edged fly ash particles often rich in quartz collide with nonsticky areas on a deposit surface causing deformation (ductile deposits) and a cutting action (brittle deposits); (2) gravity shedding, when the gravity force exceeds the tube adhesion strength; (3) through temperature changes and differences in the thermal expansion coefficients of the tube and deposit; local temperature changes may be caused by sootblowing or boiler load fluctuations; and (4) mechanically induced tension in the deposit typically caused by vibrations or sootblowing.

These mechanisms include both naturally occurring and artificially induced shedding. Natural shedding includes processes such as surface melting, erosion, and thermal shock. Steam, water, and air sootblowing are the most common artificial shedding techniques applied to remove deposits from superheater tubes. Biomass-fired boilers often have several sootblowers depending on the local flue gas temperature, deposit-sintering characteristics, and deposit quantity. ${ }^{14,16}$ The cleaning effectiveness depends on the sootblower location, the cleaning media applied, and the peak impact pressure (PIP) reached when sootblowing is performed. ${ }^{16-19}$ Sootblowers

Received: April 11, 2012

Revised: July 9, 2012

Published: July 9, 2012 
effectively remove fouling deposits, but to ensure maximum boiler thermal efficiency, cost-effective use of sootblowers is also important, because these may consume a significant percentage of the boiler steam production. ${ }^{20}$ In addition, a high superheater temperature $\left(>550{ }^{\circ} \mathrm{C}\right)$ is needed due to the corresponding increased electrical efficiency, and therefore deposit shedding at elevated superheater temperatures is of significant interest. ${ }^{20}$ Optimization of plant sootblowing and other deposit shedding conditions is important to facilitate efficient removal of deposits from biomass-fired boilers.

Full-scale deposition and shedding measurements provide useful and real information with respect to better understanding of deposit shedding and minimizing fouling and slagging in biomass-fired boilers. Ash deposit shedding through surface melting in the high-temperature superheater region at the Avedøre straw grate-fired boiler was investigated by Zbogar et al. ${ }^{21}$ The results showed that deposit surface melting is the main mechanism of straw ash deposit shedding, at flue gas temperatures $>1000{ }^{\circ} \mathrm{C}$. Deposit shedding in the Avedøre straw grate-fired boiler was investigated by Zhou et al. ${ }^{20}$ by using an artificial sootblowing probe in the superheater region nearer the convective pass at flue gas temperatures between 700 and 800 ${ }^{\circ} \mathrm{C}$. Most deposit shedding studies have been based on measurements in laboratory-scale equipment, ${ }^{18,22}$ grate-fired boilers, ${ }^{20,21}$ and Kraft recovery boilers, ${ }^{23}$ whereas only a limited amount of data is available from biomass suspension-firing. ${ }^{24-27}$

The aim of this study was to investigate deposit buildup and shedding in a $350 \mathrm{MW}_{\text {th }}$ suspension-fired boiler, firing straw and wood. Paper 1 in this series ${ }^{24}$ dealt with deposit formation, whereas this paper deals with shedding. An advanced probe was used to collect ash deposits and shedding data, which are then used to quantify naturally occurring shedding and shedding caused by plant sootblowing.

\section{EXPERIMENTAL SECTION}

Boiler. The probe measurements were conducted at Amager Power Station, Unit 1 (AMV1). The AMV1 boiler is a multifuel suspensionfired boiler, which was commissioned in 2009 to fire pulverized biomass (in the shape of crushed pellets) with various shares of straw and wood. The annual biomass consumption (at AMV1) is approximately 300,000 tons of wood pellets and 100,000 tons of straw pellets. The $350 \mathrm{MW}_{\text {th }}$ boiler is front wall-fired, having 12 burners located in three levels. Due to an expected increase in the corrosion rate with respect to temperature, the final steam temperatures of the superheaters are limited to approximately $540{ }^{\circ} \mathrm{C} .{ }^{28}$ The boiler data are shown in Table 1, whereas a schematic drawing of the boiler is shown in Figure 1 (more details can be seen in paper $1^{24}$ ).

Ash Deposition and Sootblowing Probe. The advanced deposit probe was made of stainless steel, about $3 \mathrm{~m}$ long with an outer diameter of $40.5 \mathrm{~mm}$. More details of the deposit probe can be found in other publications. ${ }^{21,24}$

The flue gas temperature near the probe was continuously measured, using a simple thermocouple in a protective shell. In addition, a suction pyrometer (International Flame Research

\section{Table 1. Brief Operational Data of the AMV1 Boiler}

\section{boiler cross-sectional area}

(at probe measuring position)

$$
5.75 \times 12.5 \sim 12 \mathrm{~m}^{2}
$$

parameter (steam)

temperature $\left({ }^{\circ} \mathrm{C}\right)$

pressure (bar)

flow $(\mathrm{kg} / \mathrm{s})$ high-pressure (HP) superheater

540 (biomass)

185

138.4 reheater $(\mathrm{RH})$

540

75

123

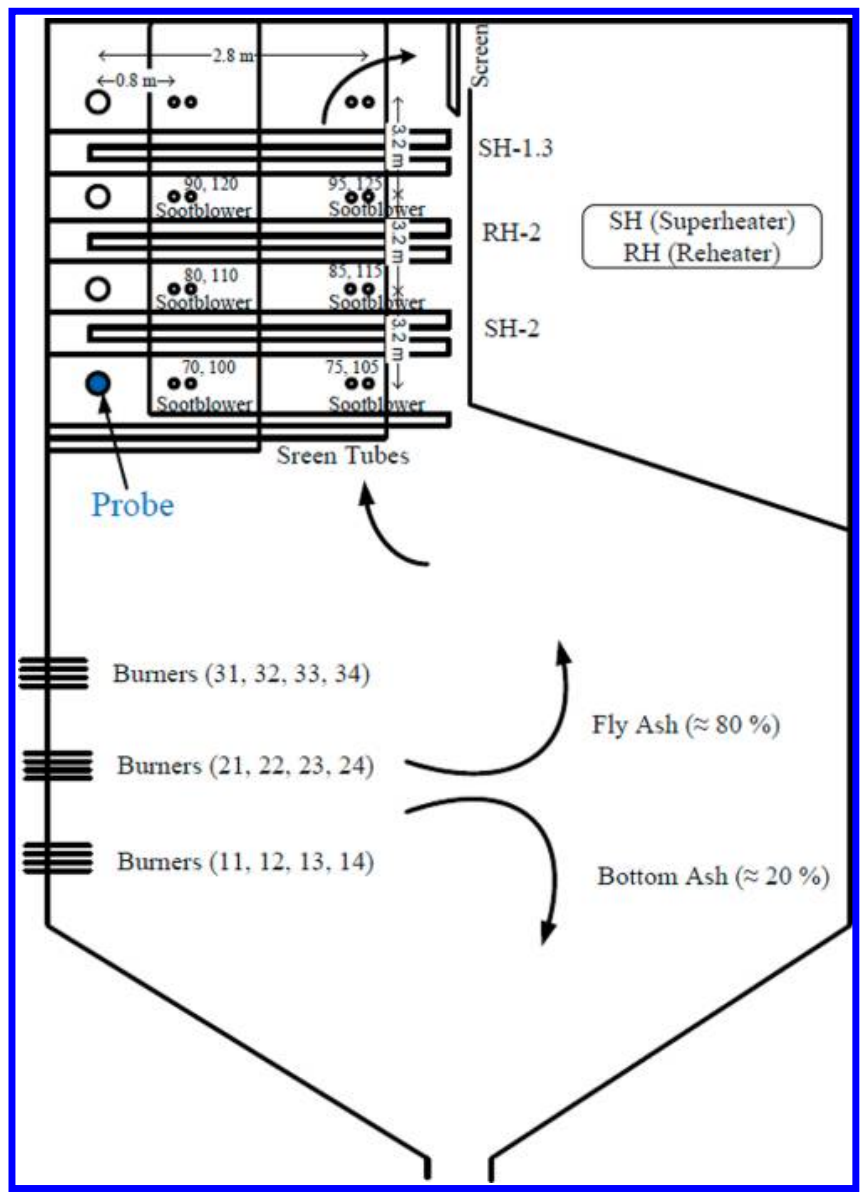

Figure 1. Schematic drawing of the AMV1 boiler outlining the position of the plant sootblowing near the experimental setup. In total, 12 sootblowers affect the deposit shedding process, 6 along the left wall of the boiler and 6 along the right wall of the boiler. The distance of each sootblower from the probe measuring position is also shown. Sootblower 70 was very near the probe measuring position $(1 \mathrm{~m}$ to the left) and was shut down during tests $1-5$. The first number in a pair of two numbers shows the sootblowers located on the same wall where the probe is located (left wall, burner location), whereas the second number shows the sootblowers located on the opposite wall (right wall, burner location).

Foundation model, $\operatorname{IFRF}^{29}$ ) was also used for shorter periods in each test, to find the difference between the thermocouple flue gas temperature measurements and the true flue gas temperature measurements. On the basis of these data, corrected thermocouple temperatures were calculated (see paper $1^{24}$ ). A charge-coupled device (CCD) camera was used to register the deposit formation and shedding processes on the probe. A schematic of the complete port setup used during the measurements can be seen in paper $1 .^{24}$

An artificial sootblowing probe with an external diameter of 42.2 $\mathrm{mm}$ and a length of $3 \mathrm{~m}$ was used for in situ removal of deposits. The schematic drawing of the sootblowing probe is shown in Figure 2a, and the detailed sootblower nozzle drawing can be seen in Figure $2 b$. The air pressure to the sootblowing probe was measured by using a pressure gauge, and the air pressure was increased in steps. The sootblowing probe was cooled by water. In the large port (please refer to part 1 of the current series of paper $^{24}$ ), a small port for the ash deposition probe, a port for the thermoelement, a CCD camera port, and a port for artificial sootblowing probe were placed. The sootblowing probe was placed parallel to the deposit probe. The sootblower probe nozzle was of convergent-divergent shape, and air at a supply pressure of 6.0 bar was fully expanded. ${ }^{17}$ The sootblower nozzle was fixed at the end of the probe. The PIP of the nozzle was measured along the axial centerline as a function of the supplied air 


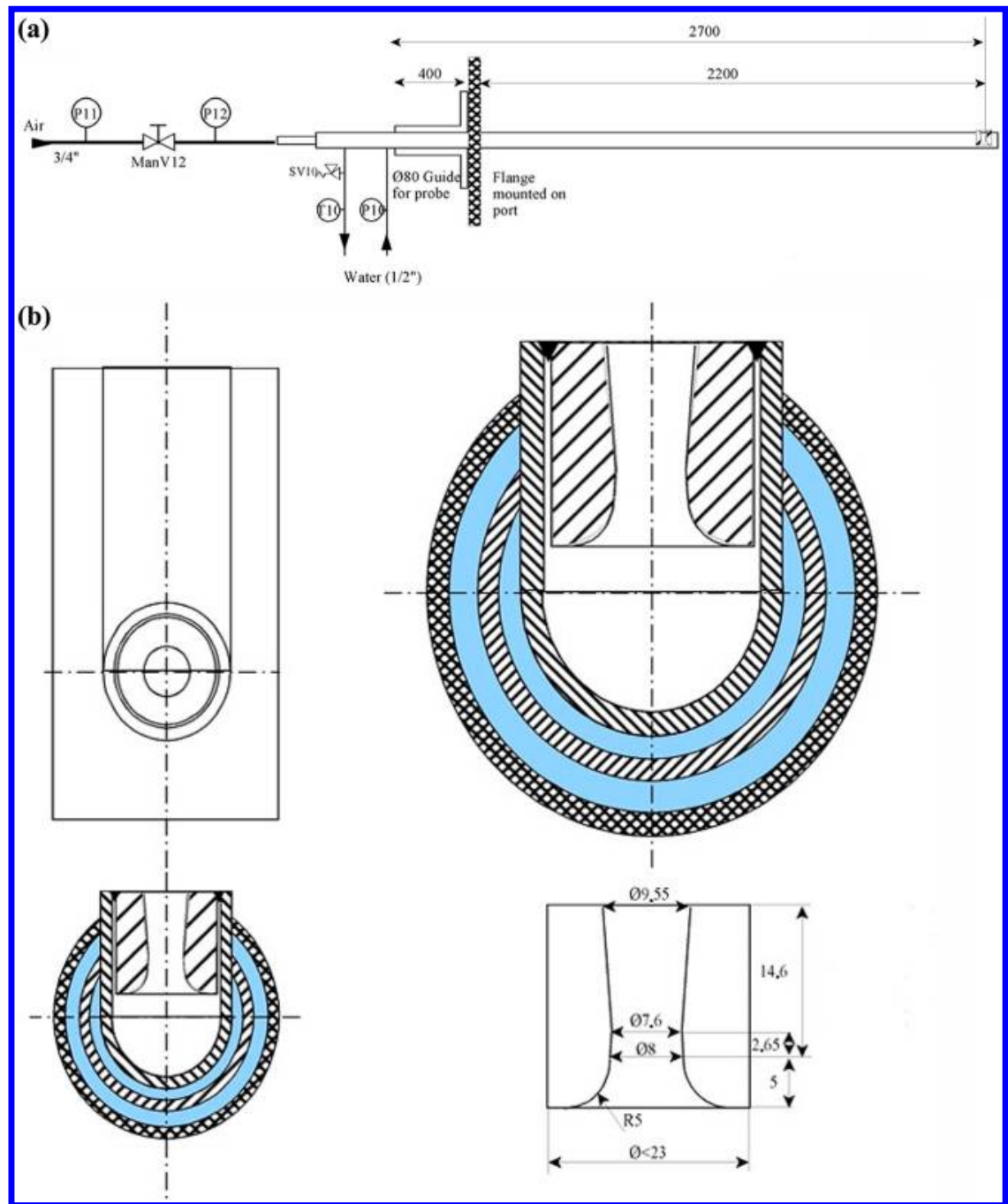

Figure 2. (a) Schematic of sootblowing probe with water and air flow description: P10, P11, and P12 are pressure gauges for air, P10 is a pressure gauge for water (to act as a cooling medium), and T10 is temperature indicator. (b) Detailed drawings of the sootblowing nozzle.

pressure in the laboratory at room temperature. The PIP of the jet, defined as the centerline stagnation pressure of the jet, was used to define the removal of deposits by the sootblowing probe. ${ }^{17}$ The measured values of PIP are shown in Figure 3, and it is important to note that these values are measured at room temperature. In the applied range of PIP, there can be a minor impact of flue gas temperature on PIP, but the measurement of PIP at temperatures close to the flue gas temperature was not possible. The measured PIP increases with the supplied air pressure and drops off quickly with the axial distance from the nozzle exit (Figure 3).

Fuels. During the measurements, fuels were continuously sampled before the burners. The total ash contents of the fuel samples collected from all test runs were analyzed, and thereby the straw fuel fractions were determined on the basis of the total ash contents. In some cases also detailed ash analysis was made as shown in Table 2 . The analysis methods and the detailed ash analysis of pure fuels and some samples from tests 1 and 5 are shown in Table 2. It is seen that the straw ash has high contents of $\mathrm{Si}, \mathrm{K}, \mathrm{Cl}$, and $\mathrm{Ca}$.

Overall, eight test runs were carried out, and the mean straw share during each test is shown in Table 3 . The slight difference in fuel ash contents shown in Tables 2 and 3 is due to the fact that in Table 3 mean values of each complete test are shown, whereas in Table 2, values are shown for a sample collected just before the burners. It is also important to mention that pure straw and wood fuel samples shown in Table 2 were collected from the fuel silos, whereas fuel sample just before the burners was collected almost each day during each test. In the start of test 5 , the fraction of straw in fuel was low (about 14 wt \%, not shown in Table 2); therefore, the overall percentage of straw in fuel was low compared to the fuel samples of test 5 shown in Table 2.

Procedure of Experiments. Ash Deposition Experiments. Measurements were conducted in the superheater region, just above the screen tubes (Figure 1). The influence of fuel type (straw share in wood), flue gas temperature $\left(600-1050{ }^{\circ} \mathrm{C}\right)$, probe surface temperature $\left(500\right.$ and $\left.600{ }^{\circ} \mathrm{C}\right)$, and deposit mass load on ash deposit formation rate was investigated. Description of ash deposition equipment and detailed interpretation of results can be found in paper $1 .^{24}$

Evaluation of probe heat uptake as a function of deposit mass load was also made for each test. A complete overview of all the conducted measurements is presented in Table 3. Additional information, for example, air flow rate, fuel flow rate, ash flux, etc., of each test is also shown in Table 3.

Artificial Sootblowing Experiments. Three different methods were used to quantify the PIP needed to remove the deposits on the probe (see Figure 4). In method 1, the sootblowing probe was placed parallel to the ash deposition probe and artificial sootblowing was started from the tip of the deposition probe with air pressure ranging from 0.5 to 4.0 bar. Method 2 is actually a continuation of method 1 , where the sootblowing probe was slightly pulled out (approximately $20 \mathrm{~cm}$ ) to remove remaining layers of the deposits by using the same principle adopted in method 1 . This procedure was repeated until the nozzle of the sootblowing probe reached a distance of $1.5 \mathrm{~m}$ from the tip of the ash deposition probe. If the amount of deposits removed was not 


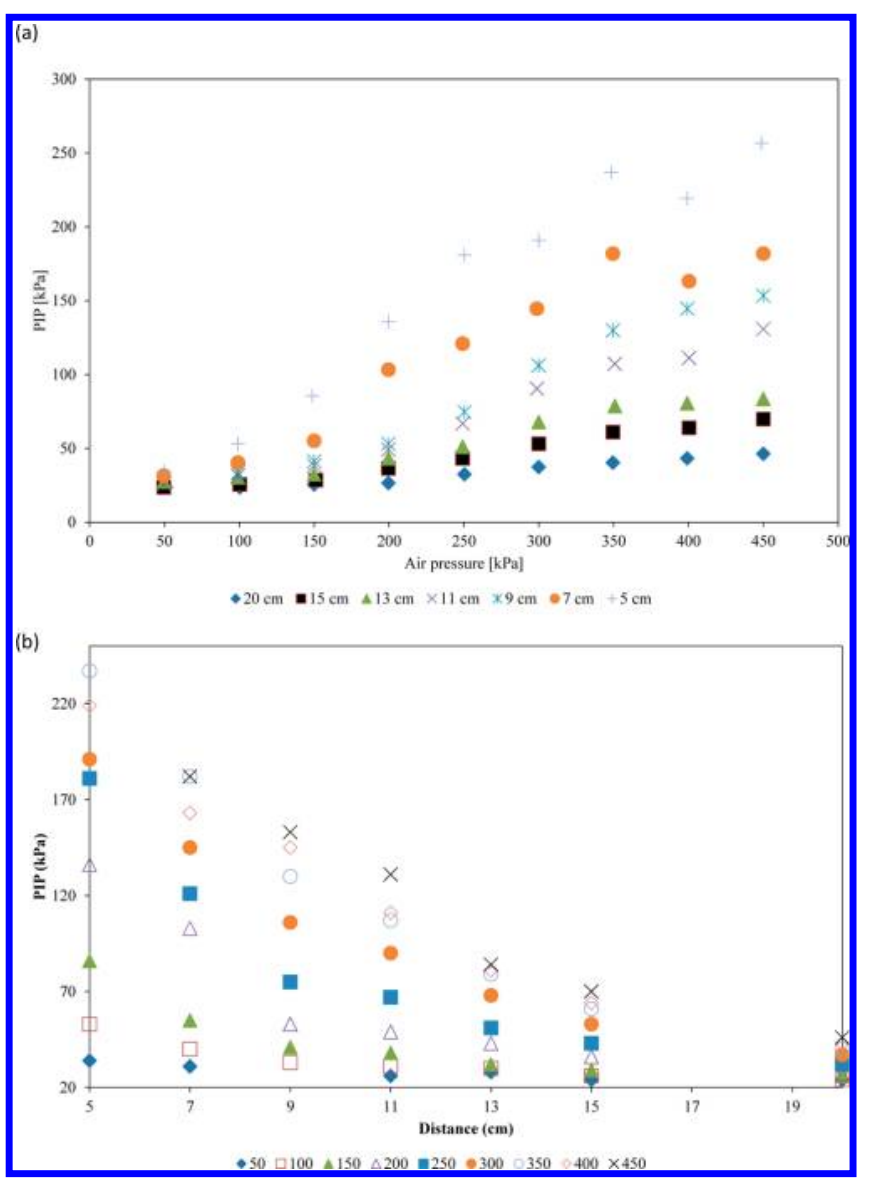

Figure 3. Measured peak impact pressure (PIP) as a function of (a) applied air pressure at various downstream distances from the nozzle exit to the deposit probe at room temperature and (b) distance from the nozzle exit to the deposit probe at various pressures at room temperature.

significant, method 3 was applied by reducing the distance between the nozzle and the deposition probe in the range of $5-20 \mathrm{~cm}$, to achieve maximum values of PIP. In each position, the impact of air on the deposit probe was from a couple of seconds to a minute. In addition, in each method, the air pressure was increased in steps. The sootblowing probe was not rotated and was only pulled or moved closer to the deposit probe. During the artificial sootblowing, camera images were collected to confirm the observed changes in the deposit mass uptake signals.

Plant Sootblowing. In the superheater region area of the boiler, retractable steam sootblowers were used for a time of 5-10 min (each sootblower) at regular intervals during boiler operation, typically at $8 \mathrm{~h}$ intervals. Six sootblowers were placed along the left wall of the boiler and six along the right wall of the boiler as shown in Figure 1. The sootblower located nearest the probe measuring position (approximately $1 \mathrm{~m}$ to the left) was shut down during tests $1-5$, whereas the rest of the sootblowers located farther away from the probe measuring position were in operation during all tests.

\section{RESULTS AND DISCUSSION}

Ash Deposit Formation Rate. The total amount of deposit collected on the probe is a function of both the deposit formation process and shedding events. Two different measures of deposit formation rate were used in the analysis of the data. The first is the integral deposit formation rate (IDF rate) found by dividing the integral mass change over integral time intervals (on the order of several hours) by the time interval. A second measure, the derivative-based deposit formation rate (DDF rate), was determined by averaging the deposit mass uptake signals over short time intervals (on the order of minutes), calculating the local values of the time derivative of the mass uptake, removing large negative values signifying major shedding events, and finally time smoothing the derivatives to remove excessive noise. Further details about the deposit formation rate determinations are presented in paper $1 .^{24}$

Video Observations of Shedding Events. The deposit mass uptake signals were continuously monitored, and depositshedding events were confirmed by video recordings. The deposit mass uptake signals during test 1 are shown in Figure 5. We have divided the shedding events into naturally occurring events and sootblowing-initiated shedding events. Even when the nearby sootblower is turned off, the increased thermal and mechanical fluctuations induced by the rest of the sootblowers may increase the shedding rate. No artificial probe sootblowing measurements were conducted during test 1 .

Confirmation of some deposit shedding events was made using the images collected at 20-30 s intervals. It was found that deposit shedding was primarily through debonding from the surface of the deposit probe; an example of a deposit shedding event is shown in Figure 6. No deposit shedding through surface melting was seen in the videos collected from any of the tests, even though a flue gas temperature of $>1000$ ${ }^{\circ} \mathrm{C}$ was observed during tests 4 and 5 . Earlier investigations by Zbogar et al. ${ }^{21}$ showed shedding through surface melting in a straw grate-fired boiler, at local flue gas temperatures $>1000^{\circ} \mathrm{C}$. Possibly the high contents of $\mathrm{Si}$ and $\mathrm{Ca}$ in the fly ash of the AMV1 boiler, and the relatively lower concentrations of the inorganic volatile elements $(\mathrm{K}, \mathrm{Cl}$, and $\mathrm{S})$, cause a higher melting temperature of the ash deposits generated by the suspension-cofiring of straw and wood. ${ }^{24,30}$

Monitoring of deposit shedding from inspection holes very close to the port position revealed a small amount of deposit shedding through erosion when nonsticky, relatively large, and sharp-edged $\mathrm{SiO}_{2}$-rich fly ash particles collide with nonsticky areas on a deposit surface. A significant amount of $\mathrm{Si}$ in the fly ash formed during straw and wood suspension-firing has been reported. ${ }^{24,30}$ Generally, most of the deposits were removed by debonding, where larger pieces detached from the tube surface.

Deposit Removal (Shedding). As discussed in paper $1,{ }^{24}$ during the calculation of DDF rates, a particular negative slope cutoff level was selected to determine major shedding events accurately while still giving a satisfactory prediction of apparent DDF rates. The selected cutoff level was $-3800 \mathrm{~g} / \mathrm{m}^{2} / \mathrm{h}$ for all tests. ${ }^{24}$ This cutoff level strikes a balance between including larger shedding events in the analysis and preventing deposit mass signal noise from being counted on a shedding event. ${ }^{24}$ The selected minimum magnitude of a shedding event included in the analysis was $-105 \mathrm{~g} / \mathrm{m}^{2}$, and this was calculated by eq 1 .

$$
\begin{aligned}
& \text { minimum shedding event magnitude } \\
& =\text { slope cutoff level } \times \text { sampling interval } \\
& =-3800 \frac{\mathrm{g}}{\left(\mathrm{m}^{2} \mathrm{~h}\right)} \frac{\mathrm{h}}{(3600 \mathrm{~s})} \times 100 \mathrm{~s} \\
& =-105 \frac{\mathrm{g}}{\mathrm{m}^{2}}
\end{aligned}
$$

The flue gas temperature and deposit probe mass uptake signals are shown in Figure 5 for test 1 . The temperature measurements by the thermocouple show temperature fluctuations in the range of $500-800{ }^{\circ} \mathrm{C}$. The deposit mass 
Table 2. Analysis of Straw and Wood Pellets Used at AMV1 ${ }^{a}$

\begin{tabular}{|c|c|c|c|c|c|c|c|c|}
\hline parmeter & procedure & $\begin{array}{l}\text { straw, } \\
\text { Køge }\end{array}$ & $\begin{array}{l}\text { wood, } \\
\text { Kunda } b\end{array}$ & $\begin{array}{c}80-85 \% \text { straw, } \\
\text { test } 1\end{array}$ & $\begin{array}{c}65-70 \% \\
\text { straw, } \\
\text { test } 5\end{array}$ & $\begin{array}{c}60-65 \% \\
\text { straw, } \\
\text { test } 5\end{array}$ & $\begin{array}{c}60-65 \% \\
\text { straw, } \\
\text { test } 5\end{array}$ & $\begin{array}{c}40-45 \% \\
\text { straw, } \\
\text { test } 5\end{array}$ \\
\hline date & & & & March 22, 2010 & April 19, 2010 & $\begin{array}{l}\text { April 20, } 2010 \\
\text { (1:00 p.m.) }\end{array}$ & $\begin{array}{l}\text { April 20, } 2010 \\
\text { (5:00 p.m.) }\end{array}$ & April 21, 2010 \\
\hline ash contents (wt \%, ar) & EN 14775:2009 & 6.03 & 0.80 & 5.26 & 4.32 & 3.56 & 3.63 & 2.74 \\
\hline ash contents (wt \%, db) & EN 14775:2009 & 6.54 & 0.86 & 5.63 & 4.57 & 3.78 & 3.84 & 2.88 \\
\hline moisture (wt \%, ar) & EN 14774-3:2009 & 7.86 & 6.83 & 6.67 & 5.61 & 5.94 & 5.55 & 5.03 \\
\hline $\begin{array}{l}\text { higher heating value } \\
(\mathrm{MJ} / \mathrm{kg}, \mathrm{db})\end{array}$ & EN 14918:2010 & 18.71 & 20.47 & 17.62 & 19.68 & 19.39 & 19.35 & 19.87 \\
\hline volatiles (wt \%, db) & EN 15148:2009 & 80.91 & 85.24 & 82.87 & 82.58 & 82.15 & & 83.11 \\
\hline$C(w t \%, d b)$ & CEN/TS 15104:2006 & 50.52 & 55.54 & 51.16 & 52.44 & 52.89 & 52.57 & 53.91 \\
\hline$S($ wt $\%, d b)$ & CEN/TS 15289:2006 & 0.15 & 0.035 & 0.121 & 0.105 & 0.095 & 0.093 & 0.068 \\
\hline $\mathrm{N}($ wt \%, db) & $\begin{array}{l}\text { DS/EN ISO 10304- } \\
\text { 1:2009 }\end{array}$ & 0.59 & 0.73 & 0.8 & 0.62 & 0.63 & 0.68 & 0.75 \\
\hline $\mathrm{H}(\mathrm{wt} \%, \mathrm{db})$ & $\begin{array}{l}\text { EN 14918:2010 } \\
\text { calculated }\end{array}$ & 5.79 & 6.15 & 5.85 & 5.92 & 5.97 & 5.96 & 6.02 \\
\hline $\mathrm{O}(\mathrm{wt} \%, \mathrm{db})$ & $\begin{array}{l}\text { EN 14918:2010 } \\
\text { calculated }\end{array}$ & 36.11 & 36.68 & 36.43 & 36.19 & 36.45 & 36.67 & 36.28 \\
\hline $\mathrm{Cl}($ wt $\%, \mathrm{db})$ & $\begin{array}{l}\text { DS/EN ISO 10304- } \\
\text { 1:2009 }\end{array}$ & 0.290 & 0.003 & & 0.155 & 0.184 & 0.191 & 0.093 \\
\hline \multicolumn{9}{|l|}{ ash analysis (wt \%, db) } \\
\hline $\mathrm{Al}_{2} \mathrm{O}_{3}$ & DIN 51729/ASTM3682 & 0.66 & & 0.95 & 1.88 & 1.30 & 0.97 & 2.11 \\
\hline $\mathrm{CaO}$ & DIN 51729/ASTM3682 & 14.56 & & 8.30 & 9.97 & 11.05 & 11.80 & 17.69 \\
\hline $\mathrm{Fe}_{2} \mathrm{O}_{3}$ & DIN 51729/ASTM3682 & 0.50 & & 0.47 & 6.81 & 1.03 & 0.58 & 1.13 \\
\hline $\mathrm{K}_{2} \mathrm{O}$ & DIN 51729/ASTM3682 & 17.88 & & 15.25 & 12.58 & 15.92 & 20.41 & 13.96 \\
\hline $\mathrm{MgO}$ & DIN 51729/ASTM3682 & 3.39 & & 2.25 & 2.11 & 2.29 & 2.54 & 2.90 \\
\hline $\mathrm{Na}_{2} \mathrm{O}$ & DIN 51729/ASTM3682 & 0.69 & & 0.57 & 0.59 & 0.87 & 1.04 & 1.03 \\
\hline $\mathrm{P}_{2} \mathrm{O}_{5}$ & DIN 51729/ASTM3682 & 5.56 & & 2.47 & 2.17 & 2.46 & 2.60 & 2.13 \\
\hline $\mathrm{SO}_{3}$ & DIN 51729/ASTM3682 & 2.43 & & 2.36 & 2.03 & 2.16 & 1.88 & 2.43 \\
\hline $\mathrm{SiO}_{2}$ & DIN 51729/ASTM3682 & 44.51 & & 52.05 & 44.89 & 49.15 & 46.95 & 36.87 \\
\hline $\mathrm{TiO}_{2}$ & DIN 51729/ASTM3682 & 0.05 & & 0.06 & 0.11 & 0.10 & 0.06 & 0.13 \\
\hline
\end{tabular}

Table 3. Experimental Summary

\begin{tabular}{|c|c|c|c|c|c|c|c|c|}
\hline & test 1 & test 2 & test 3 & test 4 & test 5 & test 6 & test 7 & test 8 \\
\hline date & $\begin{array}{l}\text { March 22-25, } \\
2010\end{array}$ & $\begin{array}{l}\text { March 27-29, } \\
2010\end{array}$ & $\begin{array}{l}\text { March 29- } \\
\text { April 6, } \\
2010\end{array}$ & $\begin{array}{l}\text { April 6-9, } \\
2010\end{array}$ & $\begin{array}{l}\text { April 15-22, } \\
2010\end{array}$ & $\begin{array}{l}\text { May } 7-25, \\
2010\end{array}$ & $\begin{array}{l}\text { May 25- } \\
\text { June } 8, \\
2010\end{array}$ & $\begin{array}{l}\text { June } 8-18, \\
2010\end{array}$ \\
\hline straw (wt \%) & $80-85$ & $60-65$ & $30-35$ & $40-50$ & $40-50$ & $0-10$ & $0-10$ & $0-10$ \\
\hline $\begin{array}{l}\text { fuel ash content } \\
\text { (wt \%) }\end{array}$ & $\sim 5.2$ & $\sim 4.0$ & $\sim 2.4$ & $\sim 3.4$ & $\sim 3.4$ & $\sim 1.0$ & $\sim 1.0$ & $\sim 1.0$ \\
\hline fuel flow (kg/s) & 12.1 & 11.4 & 12.9 & 17.3 & 12.7 & 14 & 12 & 12 \\
\hline air flow $(\mathrm{kg} / \mathrm{s})$ & 114 & 103 & 106 & 130 & 107 & 124 & 116 & 112 \\
\hline $\begin{array}{l}\text { ash flux (approx) } \\
\left(\mathrm{g} / \mathrm{m}^{2} / \mathrm{h}\right)\end{array}$ & 25334 & 19382 & 12780 & 23741 & 17105 & 4439 & 4826 & 4272 \\
\hline $\begin{array}{l}\text { probe temperature } \\
\left({ }^{\circ} \mathrm{C}\right)\end{array}$ & 500 & 600 & 500 & 500 & $500(600)$ & 550 & 550 & $550(600)$ \\
\hline exposure time (h) & 56 & 45 & 185 & 73 & 168 & 434 & 335 & 212 \\
\hline $\begin{array}{l}\text { probe heat uptake } \\
\text { investigation }\end{array}$ & yes & yes & yes & yes & yes & yes & yes & yes \\
\hline artificial sootblowing & no & yes & yes & yes & yes & & & \\
\hline $\begin{array}{l}\text { naturally occurring } \\
\text { deposit shedding } \\
\text { events }\end{array}$ & yes & yes & yes & yes & yes & & & \\
\hline plant sootblowing & yes $^{a}$ & yes $^{a}$ & yes $^{a}$ & yes $^{a}$ & yes $^{a}$ & yes & yes & yes \\
\hline
\end{tabular}

uptake signals show both natural and plant sootblowing shedding events. The deposit mass uptake signal is influenced by several processes: large shedding events, smaller shedding events (observed as a sudden deposit mass loss on the curve), a relatively slow deposit buildup process, and some noise mainly caused by boiler fluctuations. Boiler fluctuations could be mechanical vibrations or large changes in boiler flow dynamics. The most severe fluctuations are observed when the boiler plant sootblowers were used. Even though the plant sootblower very near the probe was shut down, the rest of the sootblowers to some extent induced fluctuations that could cause some shedding. All shedding events are marked showing both natural 


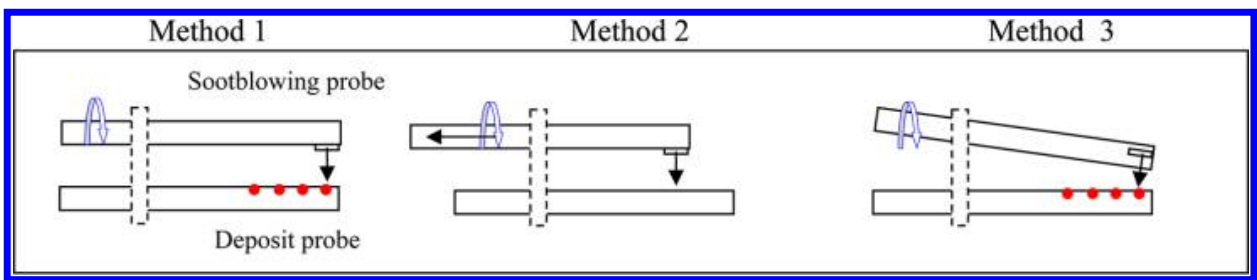

Figure 4. Experimental methods applied for artificial sootblowing.

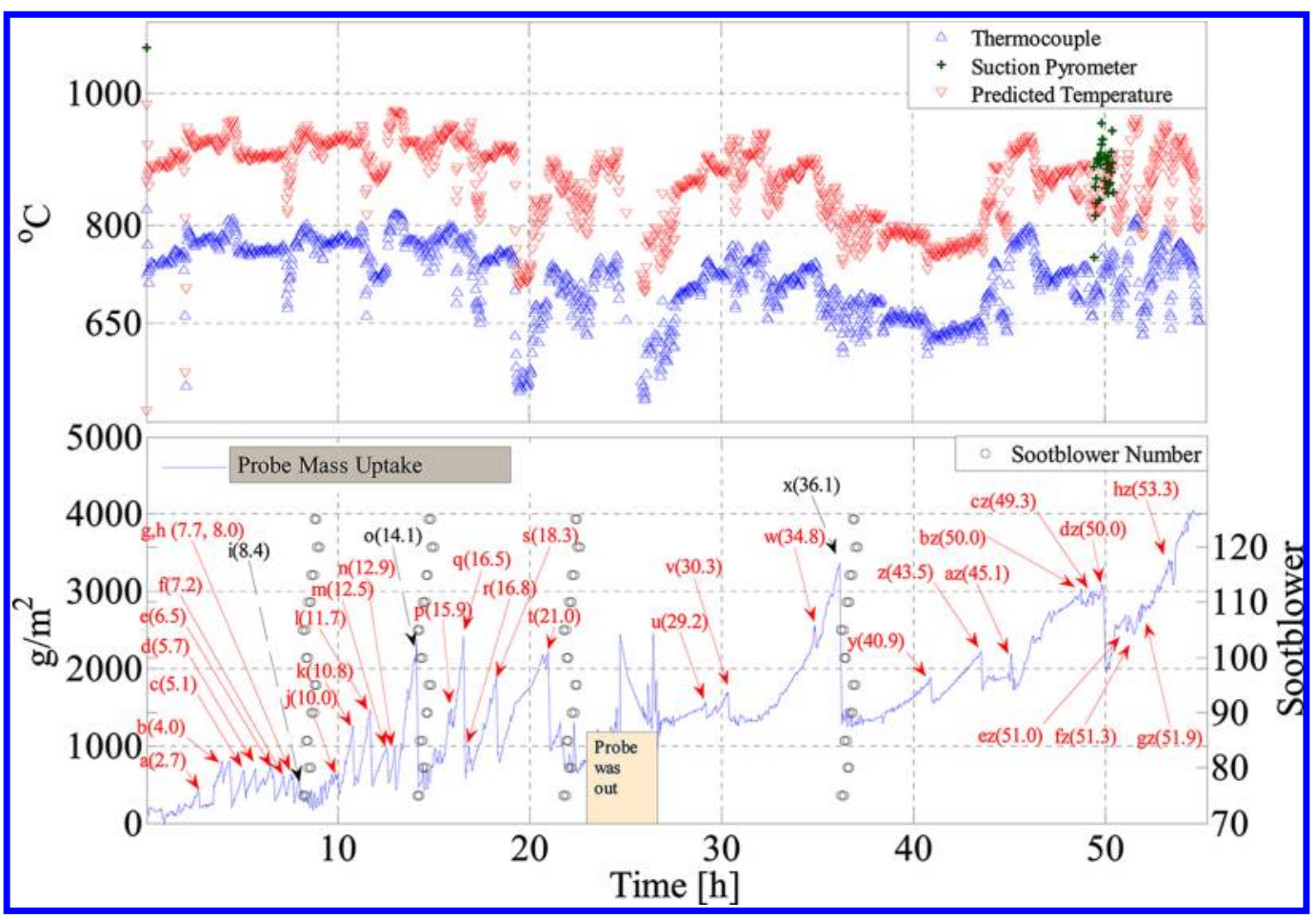

Figure 5. Data of flue gas temperature (thermocouple, suction pyrometer, and predicted ${ }^{24}$ ), probe mass uptake, and plant sootblowing events (specific number of sootblower in operation as seen on the secondary $y$-axis) during test 1 with identified shedding events. Red arrows with continuous line show natural deposit shedding events, whereas black arrows with discontinuous line show deposit shedding through plant sootblowing. Sootblower number shown on the secondary $y$-axis represents a specific sootblower in the superheater region shown in Figure 1. The number attached to each event specifies the time of the shedding event.

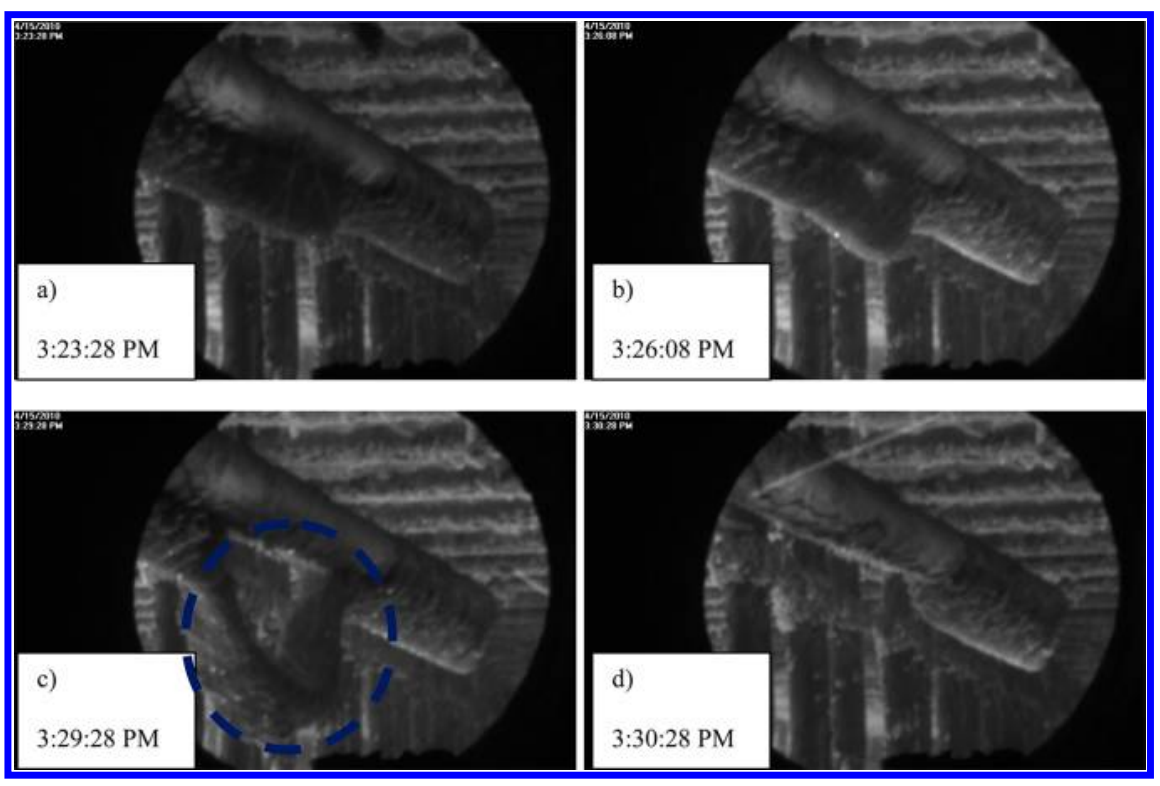

Figure 6. Images of the ash deposition probe during test 5 on May 15, 2010 (about $4 \mathrm{~h}$ of exposure time). From panels a to d, the process of natural deposit shedding through debonding can be clearly seen. 


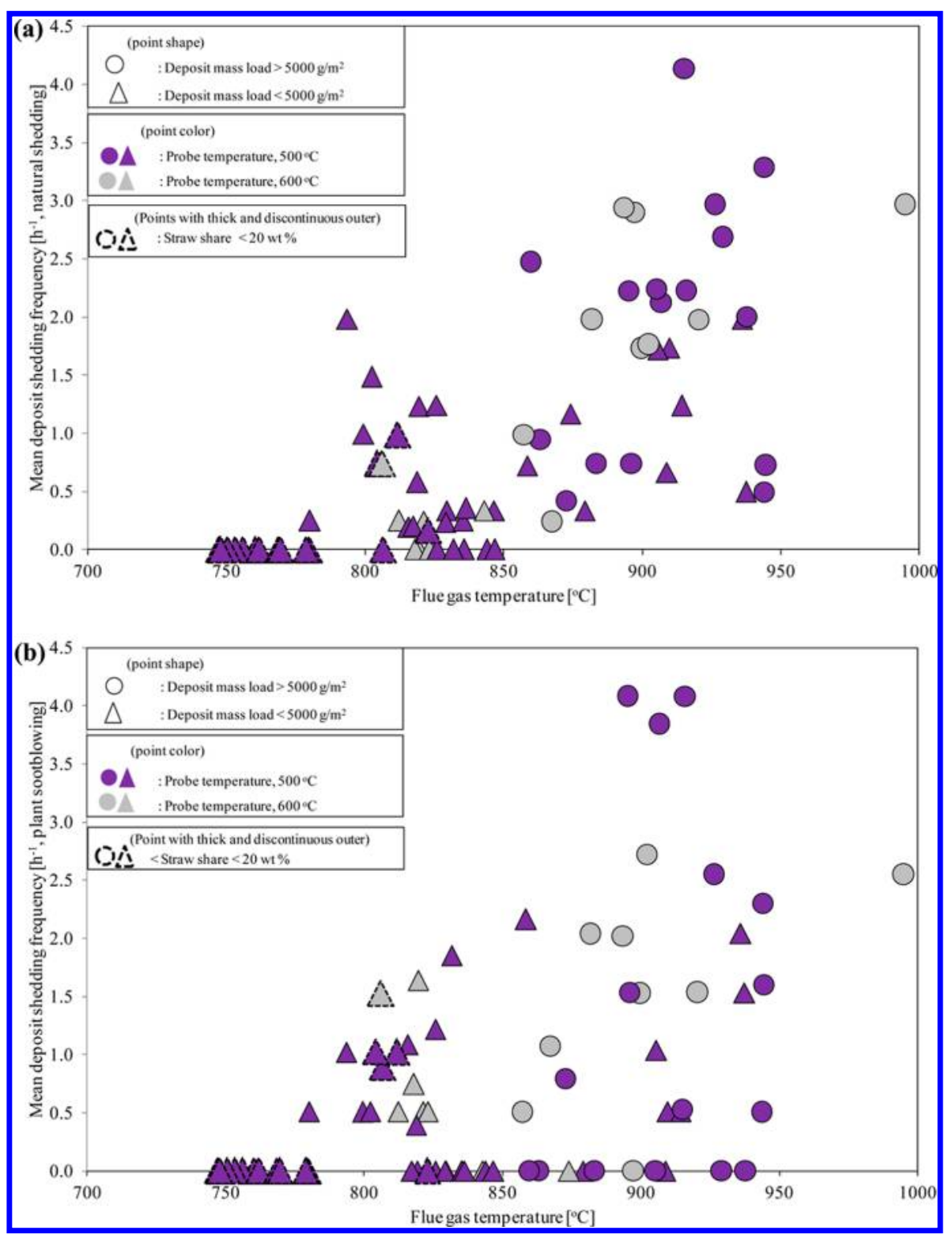

Figure 7. Impact of flue gas temperature on (a) mean natural deposit shedding frequency and (b) mean plant sootblowing shedding frequency. Data points are from tests $1-5$. The particular point shape represents the deposit mass load, and the color represents the probe surface temperature, whereas points (larger in size) with thick and discontinuous outer edges are representative of straw share in wood.

and plant sootblowing-induced shedding events. The naturally occurring shedding was defined to occur when the plant sootblowers were not in operation, and no artificial sootblowing tests were made. Sootblowing-induced shedding events can occur when the plant sootblowers are in operation. Typically, a plant sootblowing operation lasts for about $1-2 \mathrm{~h}$. The lengths of intervals between naturally occurring shedding incidents are very variable as seen in Figure 5. In the first $10-12 \mathrm{~h}$, natural shedding occurs often, but with only small amounts of material. From about 12 to $21 \mathrm{~h}$, the intervals between shedding events become longer, and the amounts removed in the single events are also larger compared to the previous period. Finally, from 29 to $55 \mathrm{~h}$, natural shedding is infrequent, but the shedding amount is again relatively small. These changes in behavior may be related to varying boiler operation parameters, but it is worth noting that during the full $55 \mathrm{~h}$, the baseline of deposited mass on the probe increased slowly from 0 to about $2500 \mathrm{~g} / \mathrm{m}^{2}$. Similar behavior was observed in most of the other tests also.
Under these conditions, analysis and quantification of natural shedding during the long time test is done by averaging over shorter time intervals. These are long enough that short time random behavior does not influence results unduly, but short enough that local operating and probe conditions may be considered fairly constant. Thus, each test was divided into sections of $6 \mathrm{~h}$, which were used for the data analysis to characterize the deposit shedding by means of magnitude of events $\left(\mathrm{g} / \mathrm{m}^{2}\right)$ and the incidence rate (deposit shedding frequency, $\mathrm{h}^{-1}$ ). With regard to natural shedding, this allowed us to calculate mean incidence rates (mean natural deposit shedding frequency), $f_{\text {nat }, 6}$, as the number of shedding events in a $6 \mathrm{~h}$ interval divided by the interval time. It should be noted that for each $6 \mathrm{~h}$ interval, the period of plant sootblowing was excluded in the evaluation of the natural shedding events. The mean deposit shedding frequency by natural shedding was calculated by eq 2 . 


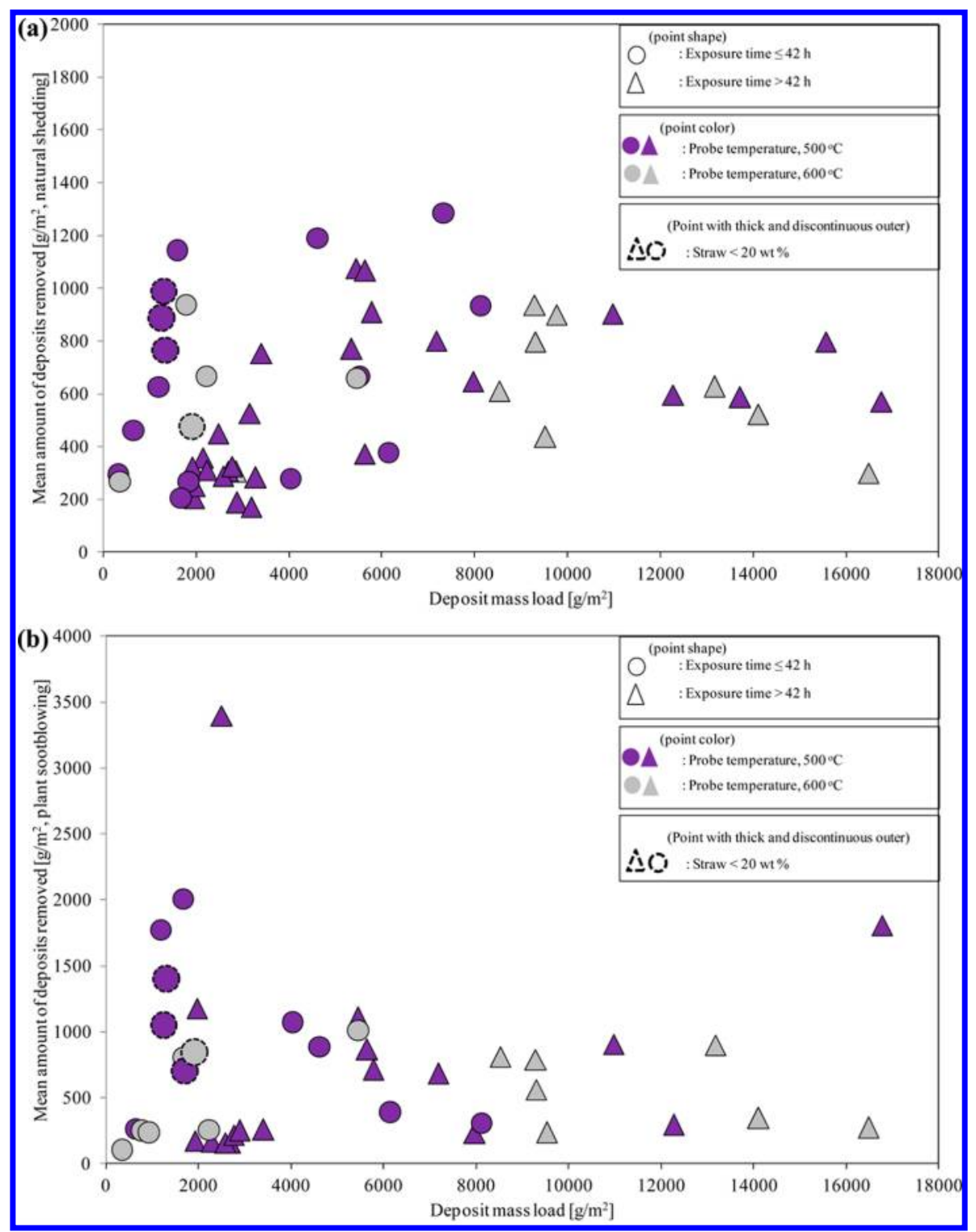

Figure 8. Impact of deposit mass load on (a) the mean amount of deposits removed naturally and (b) the mean amount of deposits removed by plant sootblowing. Data points are from tests $1-5$. The particular point shape represents the exposure time, and the color represents the probe surface temperature, whereas points (larger in size) with thick and discontinuous edges are representative of straw share in wood.

$$
\begin{aligned}
& \text { mean natural deposit shedding frequency }\left(f_{\text {nat }, 6}\right) \\
& =\frac{\text { no. of natural shedding events in a } 6 \mathrm{~h} \text { interval }}{\text { total time without plant sootblowing during a } 6 \mathrm{~h} \text { interval }}
\end{aligned}
$$

The mean plant sootblowing deposit shedding frequency was calculated by eq 3 ,

$$
\begin{aligned}
& \text { mean plant sootblowing deposit shedding frequency }\left(f_{\text {soot }, 6}\right) \\
& =\frac{\text { no. of plant sootblowing shedding events in a } 6 \mathrm{~h} \text { interval }}{\text { total time of plant sootblowing during a } 6 \mathrm{~h} \text { interval }}
\end{aligned}
$$

Influence of Different Parameters on the Shedding Process. The shedding frequency $\left(\mathrm{h}^{-1}\right)$ and the shedding event size $\left(\mathrm{g} / \mathrm{m}^{2}\right)$ are shown in Figures 7 and 8 . The mean values for $6 \mathrm{~h}$ periods with similar conditions are presented in Tables 4 (natural shedding) and 5 (sootblowing induced shedding). The shedding data are divided into groups to make it possible to analyze the influence of changed conditions in flue gas temperature (above or below $850^{\circ} \mathrm{C}$ ), probe surface temperature $\left(500\right.$ or $600{ }^{\circ} \mathrm{C}$ ), straw fuel share (weight fraction of straw in the fuel above or below $20 \%$ ), and deposit mass load (above or below $5000 \mathrm{~g} / \mathrm{m}^{2}$ ). The selected criterion of flue gas temperature is based on the results presented in paper 1 , $^{24}$ where it was found that the deposit formation rate increases significantly when the flue gas temperature exceeds $850{ }^{\circ} \mathrm{C}$. The second criterion was the probe surface temperature to investigate the influence of probe surface temperature on deposit shedding. The selected number $\left(5000 \mathrm{~g} / \mathrm{m}^{2}\right)$ for the deposit mass load is an arbitrary number, which was introduced to find any impact of deposit amount on the probe on deposit shedding. As seen in Tables 4 and 5 several of the combinations of operating conditions are without data. In two cases (straw < 20 wt \%, deposit mass load $<5000 \mathrm{~g} / \mathrm{m}^{2}$, flue gas temperature $<$ $850{ }^{\circ} \mathrm{C}$, probe surface temperature $=600{ }^{\circ} \mathrm{C}$; and straw $>20 \mathrm{wt}$ $\%$, deposit mass load $<5000 \mathrm{~g} / \mathrm{m}^{2}$, flue gas temperature $>850$ ${ }^{\circ} \mathrm{C}$, probe surface temperature $=600{ }^{\circ} \mathrm{C}$ ) only one $6 \mathrm{~h}$ period is presented. These cases are highlighted in italic type in Tables 4 and 5 , and statistically it is difficult to use those data because of 
Table 4. Summary of the Analysis of Natural Deposit Shedding for Two Different Sets of Flue Gas Temperature, Probe Surface Temperature, Straw Share, and Deposit Load

\begin{tabular}{|c|c|c|c|c|c|c|}
\hline \multicolumn{2}{|c|}{ natural deposit shedding } & \multirow{2}{*}{$\begin{array}{c}\text { flue gas temperature: } \\
\text { probe surface temperature: }\end{array}$} & \multicolumn{2}{|c|}{$<850^{\circ} \mathrm{C}$} & \multicolumn{2}{|c|}{$>850{ }^{\circ} \mathrm{C}$} \\
\hline fuel straw share & probe deposit mass load & & $500{ }^{\circ} \mathrm{C}$ & $600{ }^{\circ} \mathrm{C}$ & $500{ }^{\circ} \mathrm{C}$ & $600{ }^{\circ} \mathrm{C}$ \\
\hline \multirow[t]{14}{*}{$>20$ wt $\%$} & $>5000 \mathrm{~g} / \mathrm{m}^{2}$ & mean DDF rate $\left(\mathrm{g} / \mathrm{m}^{2} / \mathrm{h}\right)$ & & & 2691 & 1934 \\
\hline & & no. of $6 \mathrm{~h}$ periods & & & 16 & 9 \\
\hline & & no. of shedding events & & & 134 & 70 \\
\hline & & mean size of shedding event $\left(\mathrm{g} / \mathrm{m}^{2}\right)$ & & & 854 & 730 \\
\hline & & mean deposits removed (\%) & & & 10 & 7 \\
\hline & & mean shedding frequency $\left(\mathrm{h}^{-1}\right)$ & & & 1.89 & 1.92 \\
\hline & & mean shedding rate $\left(\mathrm{g} / \mathrm{m}^{2} / \mathrm{h}\right)$ & & & 1612 & 1403 \\
\hline & $<5000 \mathrm{~g} / \mathrm{m}^{2}$ & mean DDF rate $\left(\mathrm{g} / \mathrm{m}^{2} / \mathrm{h}\right)$ & 234 & 313 & 1245 & 577 \\
\hline & & no. of $6 \mathrm{~h}$ periods & 19 & 6 & 8 & 1 \\
\hline & & no. of shedding events & 42 & 4 & 38 & 7 \\
\hline & & mean size of shedding event $\left(\mathrm{g} / \mathrm{m}^{2}\right)$ & 343 & 702 & 632 & 305 \\
\hline & & mean deposits removed (\%) & 15 & 34 & 27 & 10 \\
\hline & & mean shedding frequency $\left(\mathrm{h}^{-1}\right)$ & 0.47 & 0.15 & 1.04 & 1.17 \\
\hline & & mean shedding rate $\left(\mathrm{g} / \mathrm{m}^{2} / \mathrm{h}\right)$ & 160 & 107 & 660 & 356 \\
\hline \multirow[t]{14}{*}{$<20$ wt $\%$} & $>5000 \mathrm{~g} / \mathrm{m}^{2}$ & mean DDF rate $\left(\mathrm{g} / \mathrm{m}^{2} / \mathrm{h}\right)$ & & & & \\
\hline & & no. of $6 \mathrm{~h}$ periods & & & & \\
\hline & & no. of shedding events & & & & \\
\hline & & mean size of shedding event $\left(\mathrm{g} / \mathrm{m}^{2}\right)$ & & & & \\
\hline & & mean deposits removed (\%) & & & & \\
\hline & & mean shedding frequency $\left(\mathrm{h}^{-1}\right)$ & & & & \\
\hline & & mean shedding rate $\left(\mathrm{g} / \mathrm{m}^{2} / \mathrm{h}\right)$ & & & & \\
\hline & $<5000 \mathrm{~g} / \mathrm{m}^{2}$ & mean DDF rate $\left(\mathrm{g} / \mathrm{m}^{2} / \mathrm{h}\right)$ & 221 & 1913 & & \\
\hline & & no. of $6 \mathrm{~h}$ periods & 17 & 1 & & \\
\hline & & no. of shedding events & 8 & 3 & & \\
\hline & & mean size of shedding event $\left(\mathrm{g} / \mathrm{m}^{2}\right)$ & 910 & 476 & & \\
\hline & & mean deposits removed (\%) & 44 & 28 & & \\
\hline & & mean shedding frequency $\left(\mathrm{h}^{-1}\right)$ & 0.11 & 0.74 & & \\
\hline & & mean shedding rate $\left(\mathrm{g} / \mathrm{m}^{2} / \mathrm{h}\right)$ & 101 & 353 & & \\
\hline
\end{tabular}

the limited data points. Below the influence of local changes and changes in probe conditions on the shedding characteristics is discussed.

(a) Increased Deposit Load on the Probe. The mean amount of deposit removed at a shedding event is $716 \mathrm{~g} / \mathrm{m}^{2}$ during natural shedding and $805 \mathrm{~g} / \mathrm{m}^{2}$ during sootblowing-initiated shedding as seen in Figure 8 . There are seen large fluctuations in the amount of deposit removed in a single shedding event $(6 \mathrm{~h}$ mean) from 180 to $1400 \mathrm{~g} / \mathrm{m}^{2}$ during natural shedding, but there is not observed any strong influence of the total deposit mass load on the amount of deposit removed in the single event (see Figure 8). In most cases, the probe deposit mass increases over time, and in the later stages of the experiments more than $5000 \mathrm{~g} / \mathrm{m}^{2}$ deposits are collected on the probe.

Two sets of data with similar conditions except for an increase in deposit load are available only for a flue gas temperature $>850{ }^{\circ} \mathrm{C}$, a probe temperature of $500{ }^{\circ} \mathrm{C}$, and a straw fuel share $>20$ wt $\%$ (as seen in Tables 4 and 5). Going from a deposit mass below $5000 \mathrm{~g} / \mathrm{m}^{2}$ to above $5000 \mathrm{~g} / \mathrm{m}^{2}$ changed the mean shedding event mass from 632 to $854 \mathrm{~g} / \mathrm{m}^{2}$ during natural shedding and from 935 to $849 \mathrm{~g} / \mathrm{m}^{2}$ during sootblowing-induced shedding. Again, this shows that even though the deposit mass level has a tendency to increase through time, this does not strongly influence the amount of deposit released at a shedding event. The shedding frequency is increased from 1.04 to $1.89 \mathrm{~h}^{-1}$ during natural shedding and from 1.29 to $1.56 \mathrm{~h}^{-1}$ during sootblower-induced shedding for the change from a deposit mass below $5000 \mathrm{~g} / \mathrm{m}^{2}$ to above
$5000 \mathrm{~g} / \mathrm{m}^{2}$. There is also seen a clear increase in DDF rate when the deposit mass load is increased, and because the shedding frequency increases, the shedding rate ( $\mathrm{g}$ removed/h/ $\mathrm{m}^{2}$ ) increases with the increasing deposit mass load.

Because the amount of deposit removed at a shedding event is approximately independent of the amount of deposits on the probe, the relative amount of deposits removed (relative to total amount on the probe) is larger at low probe deposit mass. In addition, video recordings of deposit removal by plant sootblowing indicate that for shorter probe exposure time, plant sootblowing removes deposits from the entire surface of the probe, whereas a complete or partial layer of deposits is removed at higher exposure times.

With regard to the shedding properties, an increased amount of deposits on the probe leads not to a significant change in the amount of deposit lost at a shedding event but to an increase in the shedding frequency and thereby the shedding rate.

(b) Changed Probe Surface Temperature. For two sets of data (temperature $<850{ }^{\circ} \mathrm{C}$, deposit mass $<5000 \mathrm{~g} / \mathrm{m}^{2}$, and a straw fuel share $>20$ wt $\%$; and temperature $>850{ }^{\circ} \mathrm{C}$, deposit mass $>5000 \mathrm{~g} / \mathrm{m}^{2}$, and a straw fuel share $>20 \mathrm{wt} \%$ ) in Tables 4 and 5 , the influence of a change in probe temperature from 500 to $600{ }^{\circ} \mathrm{C}$ is illustrated. However, no clear tendencies are observed, and a systematic change in the amount of deposit shed in an event or the deposit frequency cannot be observed when the probe temperature is changed from 500 to $600{ }^{\circ} \mathrm{C}$. However, if one looks at the mean shedding rate, then the shedding rate is in most cases higher at a probe temperature of 
Table 5. Summary of the Analysis of Shedding during Sootblower Operation for Two Different Sets of Flue Gas Temperatures, Probe Surface Temperatures, Straw Shares, and Deposit Loads

\begin{tabular}{|c|c|c|c|c|c|c|}
\hline \multicolumn{2}{|c|}{ sootblowing deposit shedding } & \multirow{2}{*}{$\begin{array}{c}\text { flue gas temperature: } \\
\text { probe surface temperature: }\end{array}$} & \multicolumn{2}{|c|}{$<850^{\circ} \mathrm{C}$} & \multicolumn{2}{|c|}{$>850{ }^{\circ} \mathrm{C}$} \\
\hline fuel straw share & probe deposit mass load & & $500{ }^{\circ} \mathrm{C}$ & $600{ }^{\circ} \mathrm{C}$ & $500{ }^{\circ} \mathrm{C}$ & $600{ }^{\circ} \mathrm{C}$ \\
\hline \multirow[t]{14}{*}{$>20$ wt $\%$} & $>5000 \mathrm{~g} / \mathrm{m}^{2}$ & mean DDF rate $\left(\mathrm{g} / \mathrm{m}^{2} / \mathrm{h}\right)$ & & & 2691 & 1934 \\
\hline & & no. of $6 \mathrm{~h}$ periods & & & 16 & 9 \\
\hline & & no. of shedding events & & & 39 & 30 \\
\hline & & mean size of shedding event $\left(\mathrm{g} / \mathrm{m}^{2}\right)$ & & & 849 & 688 \\
\hline & & mean deposits removed (\%) & & & 10 & 9 \\
\hline & & mean shedding frequency $\left(\mathrm{h}^{-1}\right)$ & & & 1.56 & 1.71 \\
\hline & & mean shedding rate $\left(\mathrm{g} / \mathrm{m}^{2} / \mathrm{h}\right)$ & & & 1322 & 1176 \\
\hline & $<5000 \mathrm{~g} / \mathrm{m}^{2}$ & mean DDF rate $\left(\mathrm{g} / \mathrm{m}^{2} / \mathrm{h}\right)$ & 234 & 313 & 1245 & \\
\hline & & no. of $6 \mathrm{~h}$ periods & 19 & 6 & 8 & \\
\hline & & no. of shedding events & 9 & 5 & 15 & \\
\hline & & mean size of shedding event $\left(\mathrm{g} / \mathrm{m}^{2}\right)$ & 750 & 332 & 935 & \\
\hline & & mean deposits removed (\%) & 20 & 32 & 42 & \\
\hline & & mean shedding frequency $\left(\mathrm{h}^{-1}\right)$ & 0.37 & 0.51 & 1.29 & \\
\hline & & mean shedding rate $\left(\mathrm{g} / \mathrm{m}^{2} / \mathrm{h}\right)$ & 278 & 170 & 1208 & \\
\hline \multirow[t]{14}{*}{$<20$ wt $\%$} & $>5000 \mathrm{~g} / \mathrm{m}^{2}$ & mean DDF rate $\left(\mathrm{g} / \mathrm{m}^{2} / \mathrm{h}\right)$ & & & & \\
\hline & & no. of $6 \mathrm{~h}$ periods & & & & \\
\hline & & no. of shedding events & & & & \\
\hline & & mean size of shedding event $\left(\mathrm{g} / \mathrm{m}^{2}\right)$ & & & & \\
\hline & & mean deposits removed (\%) & & & & \\
\hline & & mean shedding frequency $\left(\mathrm{h}^{-1}\right)$ & & & & \\
\hline & & mean shedding rate $\left(\mathrm{g} / \mathrm{m}^{2} / \mathrm{h}\right)$ & & & & \\
\hline & $<5000 \mathrm{~g} / \mathrm{m}^{2}$ & mean DDF rate $\left(\mathrm{g} / \mathrm{m}^{2} / \mathrm{h}\right)$ & 221 & 1913 & & \\
\hline & & no. of $6 \mathrm{~h}$ periods & 17 & 1 & & \\
\hline & & no. of shedding events & 8 & 3 & & \\
\hline & & mean size of shedding event $\left(\mathrm{g} / \mathrm{m}^{2}\right)$ & 965 & 845 & & \\
\hline & & mean deposits removed (\%) & 69 & 46 & & \\
\hline & & mean shedding frequency $\left(\mathrm{h}^{-1}\right)$ & 0.27 & 1.53 & & \\
\hline & & mean shedding rate $\left(\mathrm{g} / \mathrm{m}^{2} / \mathrm{h}\right)$ & 260 & 1293 & & \\
\hline
\end{tabular}

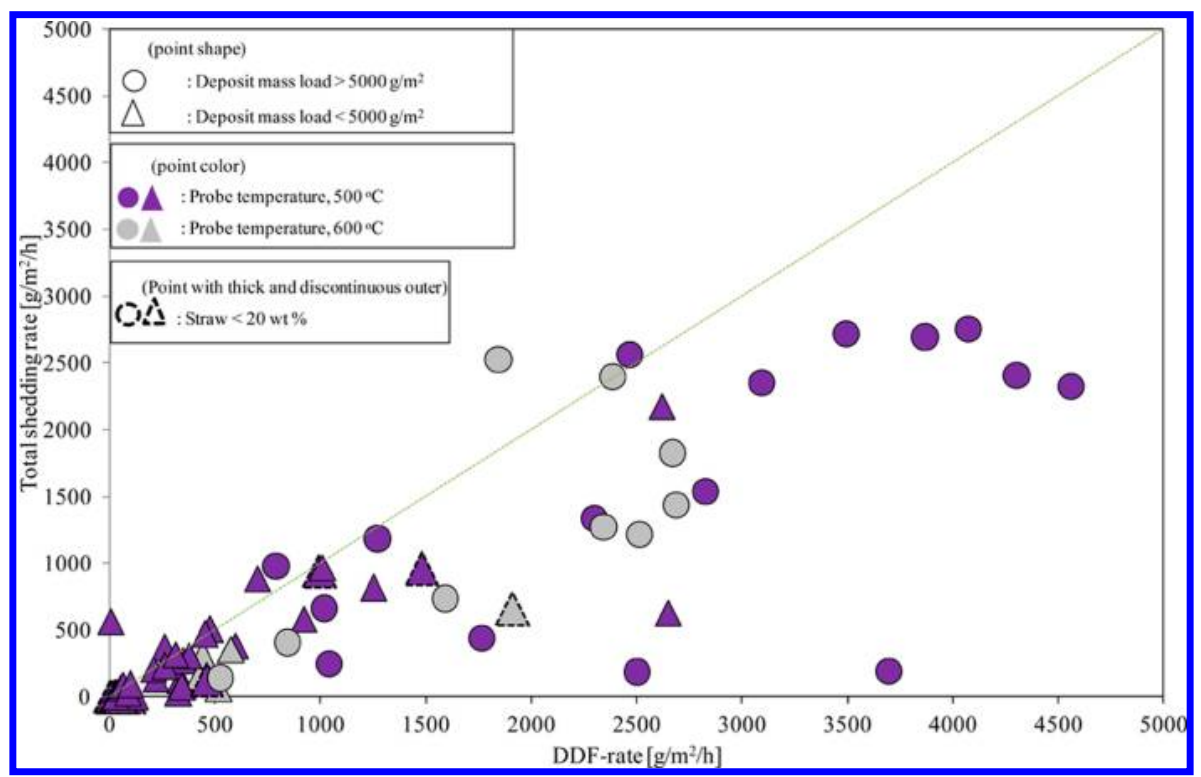

Figure 9. Total deposit shedding rate as a function of the DDF rate. Data points are from tests $1-5$. The particular point shape represents the deposit mass load, and the color represents the probe surface temperature, whereas points (larger in size) with thick and discontinuous edges are representative of straw share in wood.

$500{ }^{\circ} \mathrm{C}$ than at a probe temperature of $600{ }^{\circ} \mathrm{C}$, possibly due to partial melting and/or sintering of the innermost deposit layer (rich in $\mathrm{K}, \mathrm{Cl}$, and $\mathrm{S})^{24}$ at higher probe surface temperature. (c) Changed Flue Gas Temperature. As seen in Figure 7 an increased flue gas temperature leads to an increased deposit shedding frequency; even there is seen a very large spread in the data points. By comparison of the data sets with similar 
Table 6. Mean DDF Rates and Mean Net Deposit Accumulation Rates for Two Different Sets of Flue Gas Temperatures, Probe Surface Temperatures, Straw Shares, and Deposit Loads

\begin{tabular}{|c|c|c|c|c|c|c|}
\hline \multirow[b]{2}{*}{ fuel straw share } & \multirow[b]{2}{*}{ probe deposit mass load } & \multirow{2}{*}{$\begin{array}{c}\text { flue gas temperature: } \\
\text { probe surface temperature: }\end{array}$} & \multicolumn{2}{|c|}{$<850^{\circ} \mathrm{C}$} & \multicolumn{2}{|c|}{$>850{ }^{\circ} \mathrm{C}$} \\
\hline & & & $500{ }^{\circ} \mathrm{C}$ & $600{ }^{\circ} \mathrm{C}$ & $500{ }^{\circ} \mathrm{C}$ & $600{ }^{\circ} \mathrm{C}$ \\
\hline \multirow{12}{*}{$>20$ wt $\%$} & & mean flue gas temperature & & & $(909)^{b}$ & $(902)^{b}$ \\
\hline & $>5000 \mathrm{~g} / \mathrm{m}^{2}(9403)^{a}$ & mean DDF rate $\left(\mathrm{g} / \mathrm{m}^{2} / \mathrm{h}\right)$ & & & 2691 & 1934 \\
\hline & & no. of $6 \mathrm{~h}$ periods & & & 16 & 9 \\
\hline & & mean total deposit shedding rate $\left(\mathrm{g} / \mathrm{m}^{2} \mathrm{~h}\right)$ & & & 1537 & 1329 \\
\hline & & mean net deposit accumulation rate $\left(\mathrm{g} / \mathrm{m}^{2} / \mathrm{h}\right)$ & & & 1155 & 605 \\
\hline & & mean net deposit accumulation rate $\left(\mathrm{g} / \mathrm{m}^{2} / \mathrm{h}\right)^{c}$ & & & 957 & \\
\hline & $<5000 \mathrm{~g} / \mathrm{m}^{2}(2447)^{a}$ & mean flue gas temperature & $(823)^{b}$ & $(823)^{b}$ & $(906)^{b}$ & $(874)^{b}$ \\
\hline & & mean DDF rate $\left(\mathrm{g} / \mathrm{m}^{2} / \mathrm{h}\right)$ & 234 & 313 & 1245 & 577 \\
\hline & & no. of $6 \mathrm{~h}$ periods & 19 & 6 & 8 & 1 \\
\hline & & mean total deposit shedding rate $\left(\mathrm{g} / \mathrm{m}^{2} / \mathrm{h}\right)$ & 185 & 124 & 793 & 356 \\
\hline & & mean net deposit accumulation rate $\left(\mathrm{g} / \mathrm{m}^{2} / \mathrm{h}\right)$ & 49 & 189 & 452 & 221 \\
\hline & & mean net deposit accumulation rate $\left(\mathrm{g} / \mathrm{m}^{2} / \mathrm{h}\right)^{c}$ & 83 & & 426 & \\
\hline \multirow[t]{11}{*}{$<20$ wt $\%$} & $>5000 \mathrm{~g} / \mathrm{m}^{2}$ & mean DDF rate $\left(\mathrm{g} / \mathrm{m}^{2} / \mathrm{h}\right)$ & & & & \\
\hline & & no. of $6 \mathrm{~h}$ periods & & & & \\
\hline & & mean total deposit shedding rate $\left(\mathrm{g} / \mathrm{m}^{2} / \mathrm{h}\right)$ & & & & \\
\hline & & mean net deposit accumulation rate $\left(\mathrm{g} / \mathrm{m}^{2} \mathrm{~h}\right)$ & & & & \\
\hline & & mean net deposit accumulation rate $\left(\mathrm{g} / \mathrm{m}^{2} / \mathrm{h}\right)^{c}$ & & & & \\
\hline & $<5000 \mathrm{~g} / \mathrm{m}^{2}(792)^{a}$ & mean flue gas temperature & $(773)^{b}$ & $(806)^{b}$ & & \\
\hline & & mean DDF rate $\left(\mathrm{g} / \mathrm{m}^{2} / \mathrm{h}\right)$ & 221 & 1913 & & \\
\hline & & no. of $6 \mathrm{~h}$ periods & 17 & 1 & & \\
\hline & & mean total deposit shedding rate $\left(\mathrm{g} / \mathrm{m}^{2} / \mathrm{h}\right)$ & 147 & 660 & & \\
\hline & & mean net deposit accumulation rate $\left(\mathrm{g} / \mathrm{m}^{2} / \mathrm{h}\right)$ & 73 & 1253 & & \\
\hline & & mean net deposit accumulation rate $\left(\mathrm{g} / \mathrm{m}^{2} / \mathrm{h}\right)^{c}$ & 139 & & & \\
\hline
\end{tabular}

${ }^{a}$ Mean value of the deposit mass load. ${ }^{b}$ Mean value of the flue gas temperature. ${ }^{c}$ Mean value irrespective of probe surface temperature.

conditions (probe temperature $=500{ }^{\circ} \mathrm{C}$, deposit mass $<5000$ $\mathrm{g} / \mathrm{m}^{2}$, and a straw fuel share $>20 \mathrm{wt} \%$ ) in Tables 4 and 5 but with different flue gas temperatures (below and above $850^{\circ} \mathrm{C}$ ), there is seen an increase in shedding frequency, and a small increase in shedding mass is also observed when the flue gas temperature is increased.

(d) Increased Fraction of Straw in the Fuel. Changes in fuel straw fraction in the fuel (from above to below $20 \mathrm{wt} \%$ ) for the data sets with (probe temperature $=500{ }^{\circ} \mathrm{C}$, deposit mass < $5000 \mathrm{~g} /{ }^{2}$, and flue gas temperature $<850{ }^{\circ} \mathrm{C}$ ) show an increased shedding amount with decreased straw share. However, the mean shedding rate is low at lower straw fraction.

To summarize the main observations, the mean deposit shedding rate (shedding event amount times the shedding frequency) can be used as shown in Tables 4 and 5 .

(1) The deposit shedding rates increased at high flue gas temperatures $\left(>850{ }^{\circ} \mathrm{C}\right)$ and high probe deposit mass loads $\left(>5000 \mathrm{~g} / \mathrm{m}^{2}\right)$, at which also high deposit formation rates are observed (DDF rate).

(2) The shedding rate is in most cases higher at a probe temperature of $500{ }^{\circ} \mathrm{C}$ than at a probe temperature of $600{ }^{\circ} \mathrm{C}$. A possible reason could be partial melting and/or sintering of the innermost deposit layer (rich in $\mathrm{K}, \mathrm{Cl}$, and $\mathrm{S})^{24}$ at higher probe surface temperature. This could cause the adhesion strength of the deposit to increase at the higher probe surface temperatures.

(3) The deposit shedding process is a stochastic process, for which the amount of deposit shed varies, even at constant conditions (Figure 8). The deposit amount removed is probably strongly related to the strength of the innermost salt-rich deposit layer.
Net Deposit Accumulation Rate. The total deposit shedding rate was calculated by using eq 4 :

$$
\begin{aligned}
& \text { total deposit shedding rate } \\
& \begin{aligned}
= & (\text { natural shedding rate } \times F) \\
& +(\text { sootblowing shedding rate } \times(1-F))
\end{aligned}
\end{aligned}
$$

Here, $F$ is the fraction of time of the $6 \mathrm{~h}$ interval when plant sootblowers were not in operation. The total deposit shedding rate as a function of the DDF rate is shown in Figure 9. It can be seen that with an increase in DDF rate, the total deposit shedding rate slightly increases. It is also evident that the total deposit shedding rate is lower than the DDF rate in most cases. This causes an accumulation of deposit mass on the probe with the passage of time. The accumulation of the deposits can be presented in the form of net deposit accumulation rate, a measure of the difference between the total shedding rate and the DDF rate. In addition, it is of interest for the plant operators to quantify deposit amount finally remaining on the superheater tubes as a common result of buildup and shedding. The net deposit accumulation rate was calculated by eq 5 :

$$
\begin{aligned}
& \text { net deposit accumulation rate } \\
& \quad=\text { DDF rate - total deposit shedding rate }
\end{aligned}
$$

The calculated net deposit formation rate is shown in Table 6 for the changed conditions in flue gas temperature (above or below $\left.850{ }^{\circ} \mathrm{C}\right)$, probe surface temperature $\left(500\right.$ or $\left.600{ }^{\circ} \mathrm{C}\right)$, straw fuel share (weight fraction of straw in the fuel above or below 20\%), and deposit mass load (above or below $5000 \mathrm{~g} /$ $\mathrm{m}^{2}$ ). The main observations are the following. 


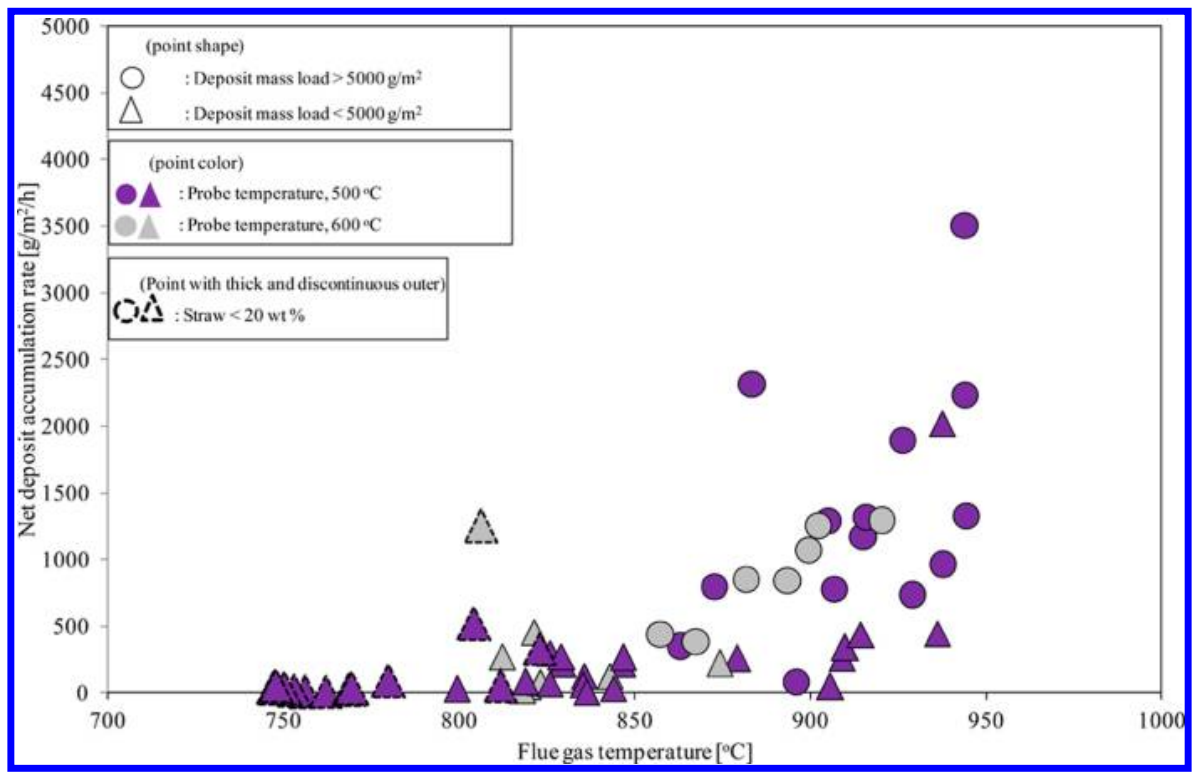

Figure 10. Impact of flue gas temperature on the net deposit accumulation rate. Data points are from tests $1-5$. The particular point shape represents the deposit mass load, and the color represents the probe surface temperature, whereas points (larger in size) with thick and discontinuous edges are representative of straw share in wood.

(1) The net deposit accumulation rate increases with increase in flue gas temperature (see Figure 10). Increased flue gas temperatures increase the fraction of molten ash as well as provide an increased content of gas phase alkali species, and both will lead to an increased deposit formation rate. The increase in DDF rate was larger than the increase in deposit shedding rate with increased flue gas temperature as shown in Table 6.

(2) The net deposit accumulation rate is low $\left(452 \mathrm{~g} / \mathrm{m}^{2} / \mathrm{h}\right)$ at lower deposit mass load $\left(<5000 \mathrm{~g} / \mathrm{m}^{2}\right)$ on the probe, compared to a value of $1155 \mathrm{~g} / \mathrm{m}^{2} / \mathrm{h}$ for deposit mass load $>$ $5000 \mathrm{~g} / \mathrm{m}^{2}$ (Table 6, probe temperature $=500{ }^{\circ} \mathrm{C}$, flue gas temperature about $900-910^{\circ} \mathrm{C}$, and straw share $>20 \mathrm{wt} \%$ ).

(3) Generally, no clear tendency for the impact of probe surface temperature on net deposit accumulation rate was seen.

Deposit Removal by Using an Artificial Sootblowing

Probe. The PIP needed in the sootblower jet to remove the probe deposits at different conditions was investigated using all three methods (1-3), and the results are summarized in Figure 11. It can be seen that increasing both probe surface temperatures and exposure times increased the PIP necessary to remove the deposits. It is also clear that deposits formed at a $500{ }^{\circ} \mathrm{C}$ probe temperature and with exposure time of $<91 \mathrm{~h}$ could be removed with a PIP of $<55 \mathrm{kPa}$. With an increase in probe surface temperature from 500 to $600{ }^{\circ} \mathrm{C}$, the PIP needed to remove the deposits significantly increased. It is also interesting to note that the PIP seems to be independent of exposure time at the higher probe temperature. The higher probe surface temperature may cause partial melting and/or sintering of the innermost deposit layer (rich in $\mathrm{K}, \mathrm{Cl}$, and S). ${ }^{24}$ This would enhance the adhesion between the deposit and superheater tube. At higher probe surface temperatures (>550 ${ }^{\circ} \mathrm{C}$ ) and longer probe exposure times, a 2-10 $\mathrm{mm}$ thick layer formed on the downstream probe surface. The layer grew to make contact with the thick upstream layer. This ring-shaped layer will be more difficult to remove, because the ring must be broken by the sootblower. At lower surface temperatures (500 ${ }^{\circ} \mathrm{C}$ ), the layer formed on the downstream side of the probe was

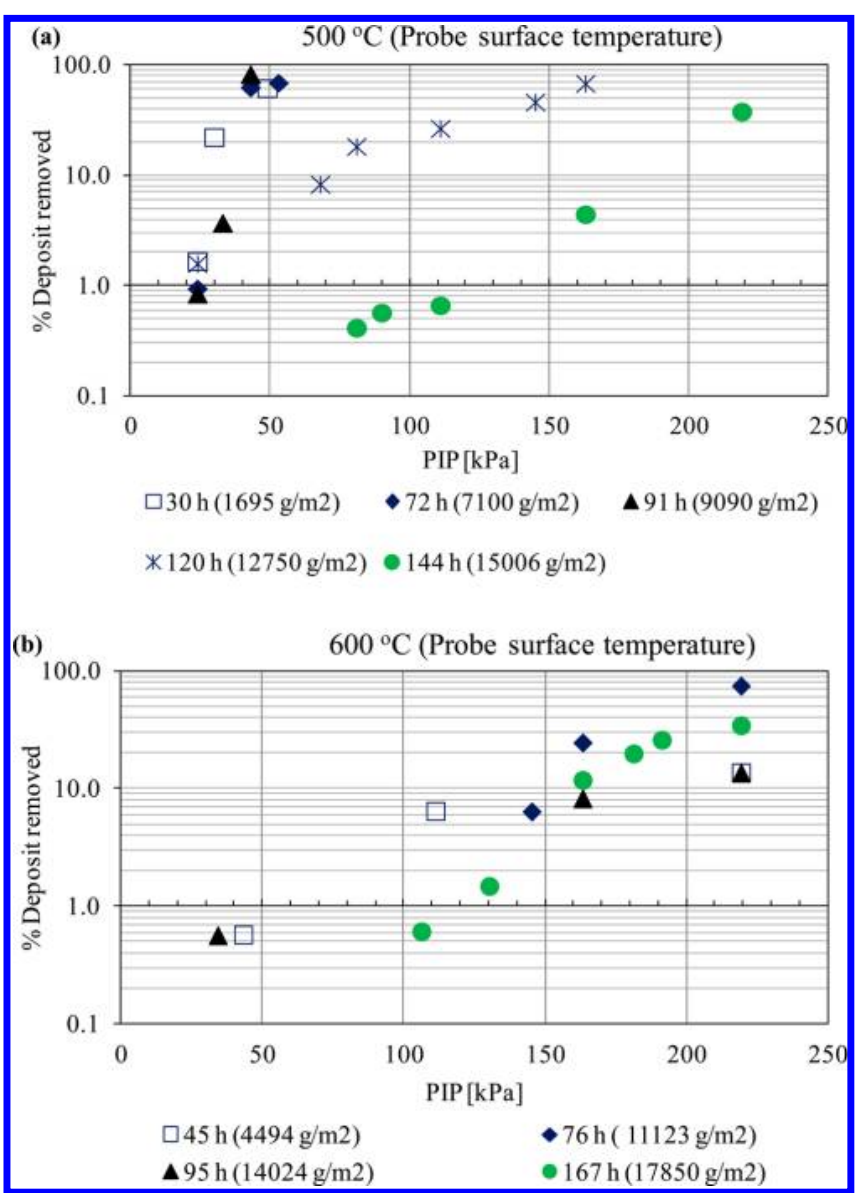

Figure 11. Percentage of deposits removed as a function of applied peak impact pressure (PIP) at different probe exposure times and deposit mass loads: (a) probe surface temperature $=500{ }^{\circ} \mathrm{C}$; (b) probe surface temperature $=600{ }^{\circ} \mathrm{C}$.

thin, and the distinct upstream layer was easy to remove using the artificial sootblower. 


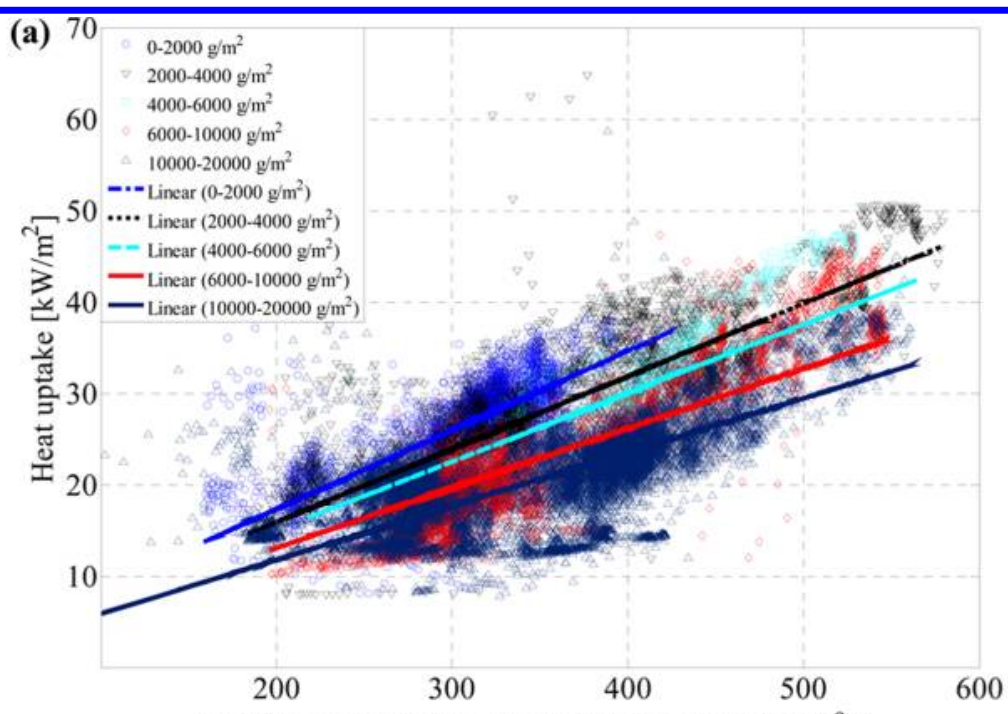

Flue gas temperature - Probe surface temperature $\left[{ }^{\circ} \mathrm{C}\right]$

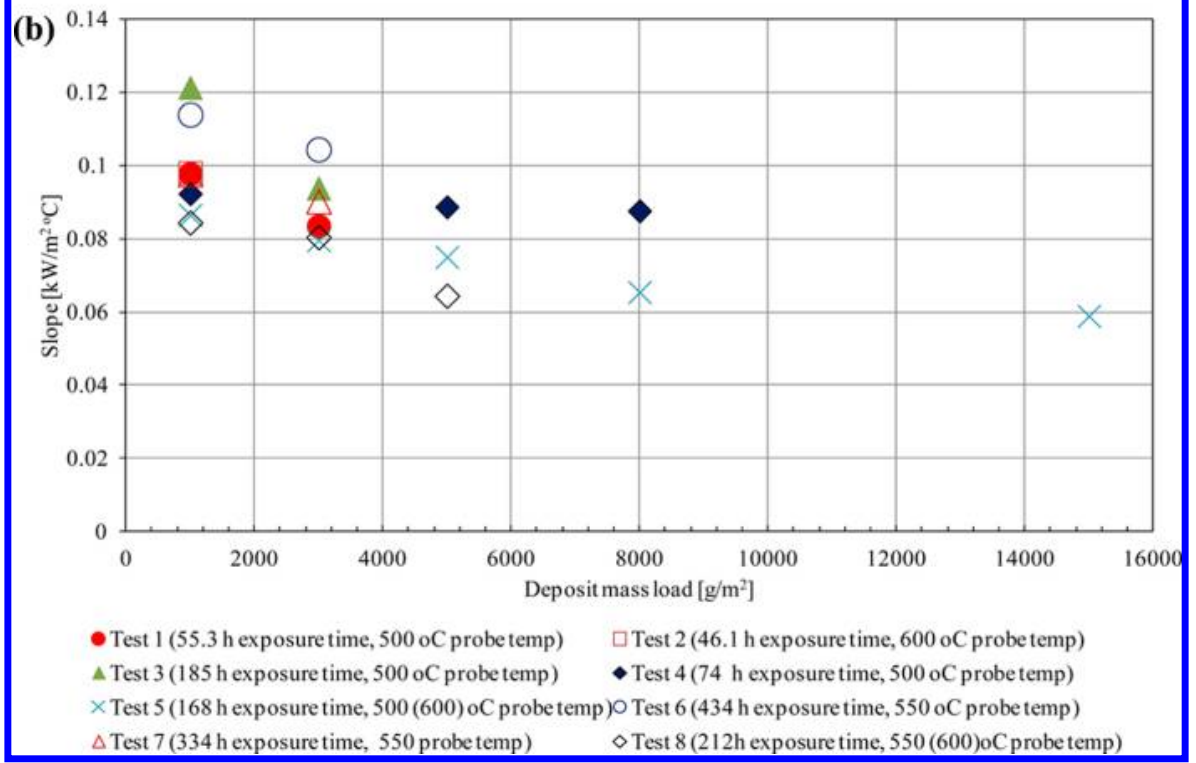

Figure 12. (a) Impact of temperature difference between flue gas and probe surface on heat uptake for different deposit mass loads for test 5 . The slope is calculated by a linear fit using the equation $y=b x$. (b) Sensitivity of heat uptake with change in temperature difference between flue gas and probe surface for different deposit mass loads for all tests $(1-8)$.

Probe Heat Uptake. The heat uptake in the probe, for different deposit mass loads during test 5 , is shown Figure 12a as a function of the difference between flue gas temperature and probe surface temperature. It can be seen that when the deposit mass load is higher $\left(>5000 \mathrm{~g} / \mathrm{m}^{2}\right)$, the slope slightly decreases due to the insulation effect of the deposit layers. The slope for different deposit loads for each test was calculated, and the combined slopes for all tests for different probe mass loads are shown in Figure 12b. A moderate reduction in the probe heat uptake was observed with increase in mass load of deposits on the probe. All of the tests provided reasonably similar results. Additionally, it can be seen that up to a deposit mass load of $5000 \mathrm{~g} / \mathrm{m}^{2}$ the reduction in heat transfer is steeper, whereafter the steepness of the curve is reduced. This is consistent with the deposit layer being more pronounced on the upstream side, so that most of the heat uptake will occur through the downstream side.

\section{CONCLUSIONS}

The overall conclusions are the following:

(1) Video recordings revealed that deposit shedding was primarily through debonding, where a deposit layer is being removed due to a breakoff of the deposit from the tube surface.

(2) It was observed that the shedding process is a stochastic process, where the amounts of deposit shed are highly variable even at constant conditions. We believe the amount of deposit shed is strongly related to the strength of the innermost saltrich deposit layer.

(3) The deposit shedding process was characterized by calculation of the average amount of deposit removed at a shedding event $\left(\mathrm{g} / \mathrm{m}^{2}\right)$ and the frequency of the shedding events $\left(\mathrm{h}^{-1}\right)$ in $6 \mathrm{~h}$ periods. The average shedding event magnitude was $716 \mathrm{~g} / \mathrm{m}^{2}$ during natural deposit shedding and $805 \mathrm{~g} / \mathrm{m}^{2}$ during plant sootblowing-induced shedding events. The shedding frequencies were 0.81 and $0.89 \mathrm{~h}^{-1}$ during natural deposit shedding and plant sootblowing-induced 
shedding events, respectively. On the basis of the shedding magnitude and frequency, it was possible to calculate a shedding rate $\left(\mathrm{g} / \mathrm{m}^{2} / \mathrm{h}\right)$.

(4) The deposit shedding rates increased at high flue gas temperatures $\left(>850{ }^{\circ} \mathrm{C}\right)$ and high probe deposit mass loads $\left(>5000 \mathrm{~g} / \mathrm{m}^{2}\right)$ at which also high deposit formation rates are observed (DDF rate).

(5) The shedding rate is in most cases higher at a probe temperature of $500{ }^{\circ} \mathrm{C}$ than at a probe temperature of $600{ }^{\circ} \mathrm{C}$.

(6) The net deposit accumulation rate increases with increase in flue gas temperature. Increased flue gas temperatures increase the fraction of molten ash as well as provide an increased content of gas phase alkali species, and both will lead to an increased deposit formation rate. The increase in DDF rate was larger than the increase in deposit-shedding rate with increased flue gas temperature.

(7) The net deposit accumulation rate is low $\left(452 \mathrm{~g} / \mathrm{m}^{2} / \mathrm{h}\right)$ at lower deposit mass load $\left(<5000 \mathrm{~g} / \mathrm{m}^{2}\right)$ on the probe, compared to a value of $1155 \mathrm{~g} / \mathrm{m}^{2} / \mathrm{h}$ for deposit mass load $>$ $5000 \mathrm{~g} / \mathrm{m}^{2}$ (probe temperature $=500{ }^{\circ} \mathrm{C}$, flue gas temperature about $900-910{ }^{\circ} \mathrm{C}$, and straw share $>20$ wt \%).

(8) Generally, no clear tendency for the impact of probe surface temperature on net deposit accumulation rate was seen.

(9) A sootblower probe was used to investigate the needed PIP to remove the deposits. At lower temperatures $\left(500{ }^{\circ} \mathrm{C}\right)$, the deposits formed at a exposure time of $<91 \mathrm{~h}$ could be removed with a PIP of $<55 \mathrm{kPa}$. At higher probe surface temperature $\left(>550{ }^{\circ} \mathrm{C}\right)$, the PIP needed to remove the probe deposits significantly increases.

\section{AUTHOR INFORMATION}

\section{Corresponding Author}

*Phone: +45 452528 49. Fax: +45 458822 58. E-mail: paj@ kt.dtu.dk.

\section{Notes}

The authors declare no competing financial interest.

\section{ACKNOWLEDGMENTS}

The financial support by Energinet.DK under the PSO Project 7217 and the financial support by Vattenfall A/S are gratefully acknowledged. We give special thanks to Vattenfall A/S for providing access to their boiler. In addition, we are thankful to the operational staff at the Amager Power Plant for their technical support during the full-scale measurements.

\section{NOMENCLATURE}

$\mathrm{CCD}=$ charge-coupled device

DDF rate $=$ derivative-based deposit formation rate $\left(\mathrm{g} / \mathrm{m}^{2} /\right.$ h)

$F=$ time fraction of $6 \mathrm{~h}$ period with no sootblower operation

$f_{\text {nat }, 6}=$ mean natural deposit shedding frequency $\left(\mathrm{h}^{-1}\right)$

$f_{\text {soot }, 6}=$ mean plant sootblowing deposit shedding frequency $\left(\mathrm{h}^{-1}\right)$

IDF rate $=$ integrated deposit formation rate $\left(\mathrm{g} / \mathrm{m}^{2} / \mathrm{h}\right)$

IFRF = International Flame Research Foundation

$\mathrm{PIP}=$ peak impact pressure $(\mathrm{kPa})$

\section{REFERENCES}

(1) Baxter, L. L. Ash deposition during biomass and coal combustion: a mechanistic approach. Biomass Bioenergy 1993, 4, 85-102.

(2) Nielsen, H. P. Deposition and high temperature corrosion in biomass-fired boilers. Ph.D. Thesis, Technical University of Denmark. 1998; ISBN 87-90142-47-0.
(3) Jenkins, B. M.; Baxter, L. L.; Miles, T. R., Jr.; Miles, T. R. Combustion properties of biomass. Fuel Process. Technol. 1998, 54, $17-46$.

(4) Miles, T. R.; Miles, T. R., Jr.; Baxter, L. L.; Bryers, R. W.; Jenkins, B. M.; Oden, L. L. Boiler deposits from firing biomass fuels. $\underline{\text { Biomass }}$ Bioenergy 1996, 10, 125-138.

(5) Baxter, L. L. Influence of ash deposit chemistry and structure on physical and transport properties. Fuel Process. Technol. 1998, 56, 8188 .

(6) Sander, B.; Henriksen, N.; Larsen, O. H.; Skriver, A.; RamsgaardNielsen, C.; Jensen, J. N.; Stærkind, K.; Livberg, H.; Thellefsen, M.; Dam-Johansen, K.; Frandsen, F. J.; van der Lans, R.; Hansen, J. Emissions, corrosion and alkali chemistry in straw-fired combined heat and power plants. Proceedings of the 1st World Conference on Biomass for Energy and Industry, Sevilla, Spain, June 5-9; James and James (Science Publishers): London, UK, 2009.

(7) Jensen, P. A.; Sander, B.; Dam-Johansen, K. Removal of K and Cl by leaching of straw char. Biomass Bioenergy 2001, 20, 447-457.

(8) Andersen, K. H.; Frandsen, F. J.; Hansen, P. F. B.; Wieck-Hansen, K.; Rasmussen, I.; Overgaard, P.; Dam-Johansen, K. Deposit formation in a $150 \mathrm{MWe}$ utility PF-boiler during co-combustion of coal and straw. Energy Fuels 2000, 14, 765-780.

(9) Jensen, P. A.; Frandsen, F. J.; Hansen, J.; Dam-Johansen, K.; Henriksen, N.; Hörlyck, S. SEM investigation of superheater deposits from biomass-fired boilers. Energy Fuels 2004, 18, 378-384.

(10) Jensen, P. A.; Sørensen, L. H.; Hu, G.; Holm, J. K.; Frandsen, F.; Henriksen, U. B. Combustion experiments with biomass fuels and additives in a suspension fired entrained flow reactor - test of $\mathrm{Ca}$ and $\mathrm{P}$ rich additives used to minimize deposition and corrosion. PSO Project: Biomass Dust Firing; CHEC Report R0504, CHEC Research Centre, Technical University of Denmark: Lyngby, Denmark, 2005.

(11) Wu, H.; Glarborg, P.; Frandsen, F. J.; Dam-Johansen, K.; Jensen, P. A. Dust-firing of straw and additives: ash chemistry and deposition behavior. Energy Fuels 2011, 25, 2862-2873.

(12) Jensen, P. A.; Zhou, H.; Frandsen, F. J.; Hansen, J. Ash deposits removal in biomass power plant boilers. Proceeding of 15th European Biomass Conference and Exhibition, Berlin, Germany, May 7-11; ETAFlorence Renewable Energies: Florence, Italy, 2007.

(13) Tobiasen, L.; Skytte, R.; Pedersen, L. S.; Pedersen, S. T.; Lindberg, M. A. Deposit characteristics after injection of additives to a Danish straw-fired suspension boiler. Fuel Process. Technol. 2007, 88, 1108-1117.

(14) Frandsen, F. J. Ash formation, deposition and corrosion when utilizing straw for heat and power production. Doctoral Thesis, Technical University of Denmark, 2011; ISBN 978-87-92481-40-5.

(15) Jensen, P. A.; Stenholm, M.; Hald, P. Deposition investigation in straw-fired boilers. Energy Fuels 1997, 11, 1048-1055.

(16) Zbogar, A.; Frandsen, F.; Jensen, P. A.; Glarborg, P. Shedding of ash deposits. Prog. Energy Combust. Sci. 2009, 35, 31-56.

(17) Jameel, M. I.; Cormack, D. E.; Tran, H.; Moskal, T. E. Sootblowing optimization, Part 1: Fundamental hydrodynamics of a soootblower nozzle and jet. Tappi I. 1994, 77, 135-142.

(18) Ebrahimi-Sabet, S. A. A laboratory study of deposit removal by debonding and its application to fireside deposits in Kraft boilers. Ph.D. Thesis, Department of Chemical Engineering and Applied Chemistry, University of Toronto, 2001; ISBN 0-612-58923-4.

(19) Stitt, S. J.; Junker, H.; Baxter, L. L. Optimization of deposit removal in biofueled boilers: review of control systems, technologies and mechanisms, Report 02-1036. Tech-wise 2002, 1-27.

(20) Zhou, H.; Frandsen, F. J.; Jensen, P. A.; Glarborg, P. PSO Project 4106, CHEC Report R0603, CHEC Research Centre, Technical University of Denmark, 2006.

(21) Zbogar, A.; Frandsen, F. J.; Jensen, P. A.; Hansen, J.; Glarborg, $\mathrm{P}$. Experimental investigation of ash deposit shedding in a straw-fired boiler. Energy Fuels 2006, 20, 512-519.

(22) Pophali, A.; Emamia, B.; Bussmanna, M.; Tran, H. Studies on sootblower jet dynamics and ash deposit removal in industrial boilers. Fuel Process. Technol. 2011, DOI: 10.1016/j.fuproc.2011.04.034. 
(23) Kaliazine, A.; Cormack, D. E.; Ebrahimi-Sabet, A.; Tran, H. The mechanics of deposit removal in kraft recovery boilers. I. Pulp Paper Sci. 1999, 25, 418-424.

(24) Bashir, M. S.; Jensen, P. A.; Frandsen, F.; Wedel, S.; DamJohansen, K.; Wadenbäck, J.; Pedersen, S. T. Suspension-firing of biomass. Part 1: Full-scale measurements of ash deposit build-up. Energy Fuels 2012, 26, 2317-2330.

(25) Bashir, M. S.; Jensen, P. A.; Frandsen, F. J.; Wedel, S.; DamJohansen, K.; Pedersen, S. T.; Wadenbäck, J. Quantification of ash deposit build-up and removal in a straw and wood suspension-fired boiler. Proceedings of 19th European Biomass Conference and Exhibition, Berlin, Germany, June 6-10; ETA-Florence Renewable Energies: Florence, Italy, 2011.

(26) Nordgren, D.; Hedman, H.; Padban, N.; Boström, D.; Öhman, M. Ash transformations. Fuel Process Technol. 2011, DOI: 10.1016/ j.fuproc.2011.05.027.

(27) Frandsen, F. J. Utilizing biomass and waste for power production - a decade of contributing to the understanding, interpretation and analysis of deposits and corrosion products. Fuel 2005, 84, 1277-1294.

(28) Gjernes, E. Fuel flexibility at Amager unit 1 using pulverized fuels. Proceedings of Power-Gen Europe, Cologne, Germany, 2006.

(29) IFRF Suction Pyrometer, User Information Document; International Flame Research Foundation: Livorno, Italy, 2010.

(30) Bashir, M. S.; Jensen, P. A.; Frandsen, F.; Wedel, S.; DamJohansen, K.; Wadenbäck, J.; Pedersen, S. T. Ash transformation and deposit build-up during biomass suspension and grate firing: full-scale experimental studies. Fuel Process. Technol. 2012, 97, 93-106. 